\author{
Doç. Dr. Fevzi KARADEMIR \\ Düzce Üniversitesi \\ Eğitim Fakültesi, \\ Türkçe ve Sosyal Bilimler Eğitimi Bölümü \\ Düzce/TÜRKIYE \\ karademir73@gmail.com \\ ORCID ID: 0000-0002-8966-6575
}

\section{AHLAK VE ETIK GÖSTERGELERININ TÜRKÇEDEKI SÖZLÜK BILIMSEL SERÜVENI ${ }^{*}$}

\author{
LEXICOLIGICAL ADVENTURE OF MORAL \\ AND ETHICAL SINGS IN TURKISH \\ LANGUAGE
}

DoI Number: 10.28981/hikmet.443163
Ahlak ve etik göstergelerinin ișaretledikleri kavramsal değer hemen her millet için hayati önem arz etmektedir. Hayati değerdeki bu tür kavramları ișaretleyen göstergelerin söz varlığına katılma süreçleri, tarihi arka planları, aileleri ve kavramsal alanlarl ile bilinmesi, gerek söz konusu kavramları bilinçli kullanma gerekse onları özümseme açısından önemlidir. Bu çalışmada Türkçenin genel sözlüğünde yer alan ahlak ve etik göstergelerinin Türkçenin söz varlığına katılma süreçleri, müteradifleri ve günümüz Türkçesindeki kullanım keyfiyetleri işlenmiştir. Bu bağlamda ahlak ve etik göstergelerinin dil bilgisel bağlamları, kullanılış anlamları ele alınmış, konuyla ilgili kavram karmaşası tartışılmıştır.

Anahtar Kelimeler: Ahlak, Etik, Moral, Söz varlığ
The conceptual value that the moral and ethical signs point at is of critical importance for all nations. Knowing the that signs point at such concepts of critical importance with their processes of accession in the vocabulary, their historical backgrounds, families, and conceptual fields is important both for using them consciously, and for internalizing them. This study deals with the processes of accession of the moral and ethical signs available in the general dictionary of Turkish language in parallel with their synonyms and their usage circumstances in the contemporary Turkish language. In this context, not only their grammatical contexts and the meanings of their use, but also the incomprehensibility in this respect are discussed hereunder.

Keywords: Moral, Ethical, Vocabulary

* Bu çalışmanın özü, 9-11.05.2018 tarihlerinde Gaziantep Üniversitesinde gerçekleştirilen Uluslararası Etik Araştırmaları Sempozyumunda bildiri olarak sunulmuştur. 
Kapılma dehrin iğfalatına ahlak bahsinde

Sana ol fende vicdanin yeter, üstat lazımsa.

Namık Kemal, Gazel

\section{Giriş}

Tıpkı insanlar gibi sözlüksel göstergelerin (sözcüklerin) de kendilerine mahsus hayat serüvenleri vardır. Onlar da bir şekilde doğar ve hayata tutunmaya çalışırlar. Onların da hayatında kökleşip gürleşme, aile kurup çoğalma veya cılız kalıp hayata veda etme; ünsiyetler, tenasüpler, tenafürler, tezatlar vardır. Onlar da yurt içi ve yurt dışı çeşitli seyahatlere çıkarlar, yerli ve yabancı unsurlarla arkadaşlık kurup izdivaç ederler.

Çok coğrafya değiştirmiş, farklı milletlerle siyasi, sosyal, kültürel etkileşime girmiş ve yine bu bağlamda türlü çalkantılar geçirmiş milletlerin dillerindeki sözlüksel göstergelerin serüvenleri daha da renklidir. Türk dili bu açıdan tipik bir örnektir. Türkçe etimolojik sözlükleri Eski Türkçeden günümüze, sözlüksel göstergelerin ne denli fonemik ve morfo-semantik değişimler geçirdiğinin örnekleri ile doludur ${ }^{1}$. Yine konuyu farklı yönleri ile işleyen çeşitli makale $^{2}$ ve kitaplar ${ }^{3}$ da sözcüklerin türlü değişim ve dönüşümlerine dair renkli levhalar sunmaktadır. Gösterilenlerin önemi nispetinde, göstergelerin bir milletin söz kadrosuna katılma süreçleri ve zaman içinde geçirdikleri morfo-semantik değişimler de önem arz etmektedir. Özellikle milletçe önemsenen kimi göstergelerdeki değişimler, aynı zamanda millet hayatındaki sosyokültürel değişimin de resmi niteliğindedir. Tanrı kelimesinin geçmişten günümüze geçirdiği değişim, bu durumun dikkate şayan örneklerindendir ${ }^{4}$.

Ahlak ve etik göstergelerinin işaretledikleri kavramsal değer de hemen her millet için hayati önem arz etmektedir. Hayati değerdeki bu tür kavramları işaretleyen göstergelerin söz varlığına katılma süreçleri, tarihi arka planları, aileleri

\footnotetext{
* Bu çalışmanın özü, 9-11.05.2018 tarihlerinde Gaziantep Üniversitesinde gerçekleştirilen Uluslararası Etik Araștırmaları Sempozyumunda bildiri olarak sunulmuştur.

${ }^{1}$ Albay (<alay+beyi), atmasyon [<Türk. atma+Fr. syon(<tion)], çapraz $(<F a r$. çep-rāst), çorap ( $<$ Ar. curāb $<$ Far. gurāb), eldiven (Far. destüvan'a benzetilerek), ortanca "çiçek adı" (< Fr. hortensia), oyunbaz (<Türk. oyun + Far. bāz), dokun+matik (Fr. automatique > otomatik'e benzetilerek), perşembe (<Fars. penc + şenbih), subaşı (Eski Türk. sü "asker" + başı), variyet (Türk. var +Ar. -iyyet) gibi sözcükler bu tür örneklerdendir (bk. http://lugatim.com/s/variyet; Tietze, 2002).

${ }^{2} \mathrm{Bu}$ makalelerden bazılarının künyeleri için bk. Güner, 2006.

3 Örnek olarak bk. Her Sözcüğün Bir Öyküsü Var (Şenyapıl1, 2003), Ayrı Düşmüş Kelimeler (Kara, 2011), Türkçede Fosil Kelimeler (Çolak, 2015).

${ }^{4}$ Eski Türkçede teñri şekliyle hem Tanrı hem de gök manasına gelen Tanrı göstergesi, Orta Türkçeden itibaren Müslüman Türkler arasında gök anlamını kaybedip sadece Tanrı anlamını kazanırken, aynı dönemde gayrimüslim Türkler arasında kelimenin Eski Türkçedeki gök manası varlığını devam ettirmiş, Tanrı anlamı umumiyetle unutulmuştur. Müslüman Türkler arasında 13. yüzyıldan 20. yüzyılın başlarına kadar Allah kelimesinin Türkçe karşılığı olarak kullanılagelen Tanrı kelimesi, 20. yüzyıldan itibaren Batıdaki tanrı anlayışına paralel olarak Allah kavramının yanı sıra, herhangi bir dine gönderme yapılmadan soyut bir ilâh manasında da kullanılmaya başlanmıștır. Bu durum Tanrı'nın -bilhassa dindar çevrelerde- Allah karşılığında kullanılmasının sakıncalı olarak görülmesine yol açmıştır (Şen, 2012) Muhafazakâr çevrelerin Tanrı kelimesine karşı tavır almasında Cumhuriyet dönemindeki dil ve din eksenli devrimlerin önemli rolünün olduğu söylenebilir. Zira ezanın Türkçeleştirilmesi, seküler ulusalcı çevrelerin Allah kelimesi yerine Tanrı kelimesinde 1srarı, muhafazakâr çevreleri Tanrı kelimesine karşı tavır almaya itmiş, özellikle Eski Türkçeyi bilmeyen çevrelerce Tanrı'nın ladini bir kelime olarak algılanmasına neden olmuştur.
}

\section{hJ»hTh - நикмет - ت}


ve kavramsal alanları ile bilinmesi, gerek söz konusu kavramları bilinçli kullanma gerekse onları özümseme açısından ehemmiyetlidir.

$\mathrm{Bu}$ çalışmada insanca bir yaşam için hayati önem arz eden ve Türkçenin genel sözlüğünde yer alan ahlak ve etik göstergelerinin Türkçenin söz varlığına katılma süreçleri ve günümüz Türkçesindeki kullanım keyfiyetleri işlenmiştir. Çalışmanın verileri kaynak taraması yöntemi ile elde edilmiş, elde edilen sözlüksel veriler, gerçekleştirdiğimiz küçük çaplı bir anketin ${ }^{5}$ sonuçları ile teyit edilmeye çalışılmıştır.

\section{Süreçleri}

1. Ahlak ve Etik Göstergelerinin Türkçenin Söz Varlığına Katılma

Arapça kökenli olan ahlak göstergesi hulk veya huluk'un çoğulu olup seciye, tabiat, huy gibi manalara gelmektedir. Sözlükler, çoğunlukla insanın fizik yapısı için halk; mânevî yapısı için hulk göstergesinin kullanıldığını kaydeder (Lisânü'l-'Arab, “hlk” md.den akt. Çağırıcı, 1989).

Fransızca yolu ile Türkçeye giren etik (Fr. éthique) ise, köken olarak Yunanca ethos'a dayanır. Hançerlioğlu, ethos için alışkanlık, gelenek ve görenek tutumu karşılıklarını verdikten sonra, Antikçağ Yunan felsefesinin bütün töre bilimsel kavramlarının bu kelimeden türediğini belirtir (1976: 93).

Biri Doğu, diğeri Batı kültürüne ait bu iki göstergenin Türkçenin söz varlığına katılma süreçlerinin söz konusu kültürlerle etkileşim seyri ile paralellik gösterdiği, dolayısıyla ahlak'ın, Türklerin İslamiyet'le tanışmasını; etik'in ise Türklerin Batı kültürüne yönelmesini müteakip Türkçenin söz varlığına katıldığ1 açıktır.

Bununla birlikte, Türkler, Müslüman olmadan önce ahlak kavramını hangi gösterge(ler) ile karşıllıyorlardı? İslamiyet'le tanıştıktan sonra İslami öğretinin temel kavramlarından biri olan ahlak göstergesini hemen kullanmaya başladılar mı? Örneğin, biri ferdi, diğeri siyasi ahlakı etraflıca işleyen Atabetü’l Hakayık ve Kutadgu Bilig gibi ilk İslami Türk eserlerinde ahlak kelimesi geçiyor mu? Müslüman Türklerin ilk ansiklopedik sözlügü olan Divânü Lugati’t-Türk'te ahlak maddesi yer alıyor mu? Daha da önemlisi, ünü Türk sınırlarını da aşan bilge âşık Yunus Emre'nin ahlaki ögütlerinde ahlak göstergesine rastlanıyor mu? gibi soruların cevap bulması, Türklerin ahlak olgusu ile ilişkisi ve ahlak göstergesini kullanım seyri ile ilgili daha doğru bilgilere ulaşılmasını sağlayacaktır. Bu amaç doğrultusunda söz konusu sorular, aşağıda Türkçenin tarihi devirleri esas alınarak aydınlatılmaya çalışılacaktır:

\section{Eski Türkçede (Yazılı Türkçenin “YT’nin” 1. Döneminde)}

Türkler henüz Araplarla kültürel münasebet kurmadıkları için tabii olarak Türkçenin ilk yazılı kaynaklarını sunan Eski Türkçede (Köktürk ve Uygur Türkçesi) Arapça kökenli ahlak göstergesine rastlanmamaktadır.

5 100'ü lise (Düzce Atatürk Anadolu Lisesi, Düzce Arsal Anadolu Lisesi), 100’ü üniversite (Düzce Üniversitesi Eğitim Fakültesi) öğrencisi olmak üzere toplam 200 öğrenciye sırası ile hulk, etik, ahlak ve moral göstergelerinden ne anladıklarını yazmaları istenmiş, katılımcıların verdikleri cevaplar tasnif edilerek yeri geldiğinde sözlüksel verilerle karşılaştırılmıştır. (Lise öğrencilerine yönelik anketi uygulamada bana yardımcı olan edebiyat öğretmenleri İrfan Soğan ve Aydın Soylu'ya teşekkür ederim.)

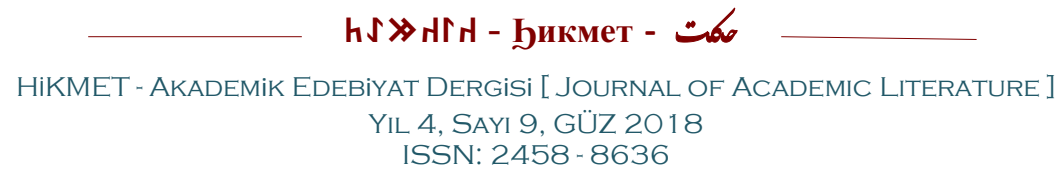


Eski Türkçede ahlak ile hemen hemen aynı kavramsal değeri taşıyan başlıca göstergeler Türkçe ķılıķ (yaradılış, huy, ahlak, karakter) ve ķılınç (1. olma, var olma 2. amel, iş, icraat, işlem 3. huy, ahlak)tır. Çahşapat ${ }^{6}[(<$ Skr. çıkşâpada, Sog̉d. çihşâpad) talimat, ahlak akidesi, kural, nizam, tanrı buyrukları...], nom (1. kanun, din, akide, inanç...), yaraş (yaradılış, tabiat), törü (töre, örf, kanun, nizam, gelenek, görenek) gibi unsurlar da ķılıķ ve ķılınç'ın çağrışım alanında sayılabilecek göstergelerdir.

Yine iyi ve kötü kimi ahlaki özellikleri belirten şu sözleri de bu bağlamda anmak gerekir: amal/amul (sakin, uslu, yavaş, halim, yumuşak huylu), arıg (temiz, saf ), biliglig (bilgili), erdemlig (1. erdemli, terbiyeli, faziletli, muktedir, kabiliyetli 2. cesaretli, mert.), onat (1. düzenli, düzgün, uygun 2. yararl1: 3. dürüst, iyi ahlakl1), ovutlug (hayalı, ahlaklı), tokurkak (kendini tok sayan, tok gözlü), tüz (barışık, uyumlu), yavaş (yumuşak huylu, sakin, halim, müşfik), çḩ̧şapatlı̀g (ahlaklı, ahlak törelerine uyan, saygı gösteren); anyı (kötü, fena.), armakçı (aldatıcı, sahtekâr), biligsiz (cahil, bilgisiz), erdemsiz (deġersiz, güçsüz), erinçülük (günahkar, suçlu), küni (kıskaçlık, haset ), tüzsüz (itaatsiz, uyumsuz, kavgalı), üz (aksi, inatçı, başına buyruk), yabız (kötü, fena), yablak (fena, kötü, kötülük ) (bk. Bayat ve Aliyeva, 2008; Tekin, 2003).

\section{Orta Türkçede (YT'nin 2. Döneminde)}

Orta Türkçe, ilk İslami Türkçe eserlerin verildiği dönem olup doğu, batı ve kuzey olmak üzere üç ayrı yönde gelişen Tarihi Türk lehçelerini kapsar. Orta Türkçenin doğu kolunun (Karahanlı Türkçesi) sembol eserleri Divanü Lügat'i-t Türk (Telif tarihi: 11. yy. bk. Ercilasun, 2014), Kutadgu Bilig (Telif tarihi: 11. yy., bk. Arat, 1979; 1999), Atabetü'l-Hakayık (Telif tarihi: 12. yy. ?, bk. Arat, 2006) ve dönemin Türkçe İlk Kur'an Tercümesi'nde ${ }^{7}$ (Telif tarihi: 12. yy.?, bk. Ata, 2004) hulk, ahlak göstergeleri yer almamaktadır. Karahanlı Türkçesi sözlükleri de (Üşenmez, 2010; Ünlü, 2012a) ahlak ve hulk göstergelerini madde baş1 olarak almamışlardır. Dolayısıyla önceki dönemde olduğu gibi, bu dönemde de ahlak göstergeleri kılık/kılığ ve kılınç’tır. Bu göstergelerin kullanımlarına dair bazı örnekler aşağıdaki gibidir:

$$
\begin{aligned}
& \text { tadu (tıynet, tabiat) birle katlıp törümiş kılınç }{ }^{8} \\
& \text { ölüm buzmağınça buzulmaz erinç } \\
& \text { karında törümiş kllınç ögretig } \\
& \text { yağız yér katında kiter ay tetig }
\end{aligned}
$$

\footnotetext{
${ }^{6}$ Soğdca çahşsapat kelimesinin kökeni ve Türkçedeki kullanımları ile ilgili ayrıntılı bilgi için bk. Erdem, 2014: 73 .

7 Çağırıcı (1989), Kur'an-1 Kerim'in orijinal metinlerinde ve orijinal hadis metinlerinde ahlak sözünün geçip geçmediği ile ilgili olarak şu tespitlerde bulunur: "Kur'ân-ı Kerîm'de ahlâk kelimesi yer almamakla birlikte, biri "âdet ve gelenek", diğeri de "ahlâk" mânasinda olmak üzere iki yerde (eş-Şuarâ 26/137; el-Kalem 68/4) ahlâkın tekili olan huluk kelimesi geçmektedir. Ayrıca pek çok âyette yer alan amel teriminin alanı ahlâkî davranışları da içine alacak şekilde geniş tutulmuştur. Bunun yanında bir (birr), takvâ, hidâyet, sırât-ı müstakım, sıdk, amel-i sâlih, hayır, mâruf, ihsan, hasene ve istikamet gibi iyi ahlâklllık; ism, dalâl, fahşâ, münker, bağy, seyyie, hevâ, israf, fisk, fücûr, hatîe, zulüm gibi kötü ahlâklılı ile aynı veya yakın anlam ifade eden birçok terim vardır. Hadislerde ise bu terimler yanında ahlâk ve hulk kelimeleri de kullanılmıştır."

${ }^{8}$ Arat'ın tespitlerine göre Kutadgu Bilig'de kılınç, 172; kılk, 235; kılık, 47 defa geçmektedir (1979: 248-251).

${ }^{9}$ İnsanın tıynetine sinmiş olan ahlâk, ölüm bozmadıkça, katiyen bozulmaz.
}

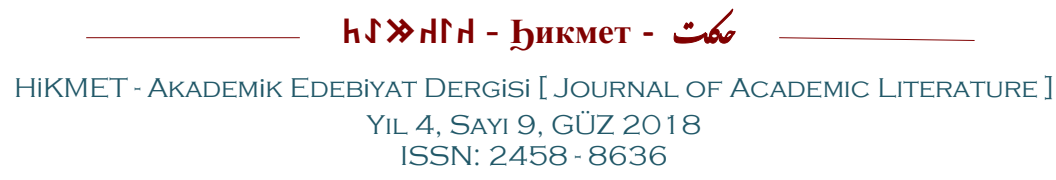


kalı edgüke bolsa isiz işi

isiz boldı kılkı ol isiz tuşl ${ }^{l 1}$

isiz me katılsa kör edgü bile

kamuğ edgülükke bu buldı yula ${ }^{12}$ (Kutadgu Bilig, Arat, 1999: 105).

tekebbür ḳamug tilde yirlür ḳllık

kıllıklarda edgü ḳllı kodkıllı

ol er kim uluğsındı men men tidi

anı ne halayı sever ne hâlik. $k^{13}$

köki körklüg erning huyı körklüg ol

bu körklüg ḳllıkka köngül örklüg ol

bir erdin bir erke tefavüt telim

velikin körerke tözü börklüg ol ${ }^{14}$

bütün kalkı fi'lin öte irtegil

kerem kimde erse anı er tigil

yimişsiz yı̆̆aç teg keremsiz kişi

yimişsiz yığaçnı kesip örtegil ${ }^{15}$ (Atabetü'l-Hakayık, Arat, 2006: 62, 66)

Karahanlı Türkçesinde âdet (huy, tabiat), haslet (huy, tabiat), huy, itig (huy, tıynet), mizac ${ }^{16}$, tab ${ }^{\circ}$, tabiat göstergeleri k1lk/k1lık, kılınç'ın başlıca anlamdaşları olarak kullanılmıştır (bk. Üşenmez, 2010; Ünlü, 2012a).

Yine bu dönemde k1lk/kılık, kılınç göstergeleri ile aynı kavram alanını paylaşan gerek Türkçe gerek alıntı çok sayıda gösterge de göze çarpmaktadır. Bu göstergelerden birkaçı aşağıdaki gibidir:

\footnotetext{
${ }^{10}$ Ana karnında teşekkül eden tabiat ve terbiye ancak kara toprak altında insanı terk edip gider; ey zeki insan.

${ }^{11}$ Eğer iyiye kötü biri arkadaş olursa, onun tabiatı de, arkadaşınınki gibi, kötü olur.

${ }^{12}$ Kötü de iyi ile düşüp-kalkarsa, bütün iyiliklere ulaşmak için, bir meşale bulmuş olur.

${ }^{13}$ Kibir, bütün dillerde yerilen bir huydur;

Huyların iyisi, alçak gönüllülüktür;

Ululuk taslayan ve benim diyen kimseyi

Ne Tanrl ve ne de kul sever.

${ }^{14}$ Aslı güzel olan adamın huyu güzel olur;

Güzel huylu adama gönül bağlanır.

Adamdan adama fark çoktur,

Fakat görünüşte hepsinin börkü vardır.

15 (Insanların) bütün tavir ve hareketlerini iyice incele,

Kerem kimde ise, ona insan de;

Keremsiz insan meyvesiz ă̆aç gibidir,

Meyvesiz ă̆acı kesip atește yak

16 Ünlü, mizacı değil, mizạ̣ (Ar. mizac)1 madde başı olarak almıştır (bk. Ünlü, 2012a).
}

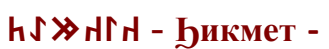


adl: (adalet), akı1ık (cömertlik), birr (iyilik, güzellik), cûd (cömertlik), edeb (terbiye, ahlak güzelliği), fazl (fazilet, lütuf, ihsan), hilm (yumuşaklık, sabır), kerem (cömertlik, ihsan), könilik (doğruruluk), mürüvvet (insaniyet, insaniyete yaraşır huy ve davranış), töre (adet, gelenek), törü (töre, kanun, nizam)...

Şunlar da sırası ile iyi ve kötü ahlaki özellikleri ifade eden sözlerdir:

açuklug (yumuşak huylu), akı/ahı (cömert), arıg (temiz), silig (temiz), süzük (duru, temiz), uvutlug (hayâ sahibi), tüzün (yumusak huylu, asil), tedük (temiz, saf), bütün (doğru, dürüst), çın (doğru), ınal (inanılır, güvenilir), ködrüm (yüksek, seçkin), tüz (temiz kalpli, asil), edgü (iyi), alçak (alçak gönüllü, yumusak huylu), bağırsak (merhametli, sefkatli, sadakatli, temiz kalpli), erdemlig (erdemli, faziletli), bışıg (olgun), köni (doğru), talu (seçme, nadide), ödründü (seçilmiş), ödrüm (seçilmiş), sahavetlı $\dot{\mathrm{g}}$ (cömert).

aslı arıg, urgı arıg, aslı silig, köngli süzük, köngli tüzük, kılınçı silig, kılınçı ongay, kılınçı köni, kılınçı tüzün, kerim (kerem sahibi), kılkı arıg, kılkı silig, k1lk1 tüze, k1lk1 ongay, k1lk1 köni, k1lk1 alçak, k1lk1 tüzün, k1lk1 edgü, k1lk1 örüng...

arıgsız (temiz olmayan), bahil (hasis, cimri), ınga (daha kötü, en kötü; alçak, namussuz), k1lk1 otun (kaba tabiatlı), otun (değersiz, alçak), törüsüz (düzensiz), urugsuz (soysuz), yavız (kötü, fena), yazuklu (günahlı, suçlu, hatalı, kusurlu), yüzçi (iki yüzlü, mürai)... (bk. Böler, 2009; Üşenmez, 2010; Ünlü, 2012a; Ercilasun, 2014).

Karahanlı Türkçesinin devamı sayılan Harezm Türkçesinde kı1ık/kılıg், kılınç'ın yanı sıra hulk ve ahlak göstergelerinin de kullanıldığı tanıklanmıştır (bk. Ünlü, 2012b). Ancak bu göstergelerin kullanım sıklığı eserden esere farklılık göstermektedir. Örneğin, dönemin meşhur eserlerinden Nehcü'l-Ferâdis'te (Telif tarihi: 14. yy, bk. Ata, 1998) kılık, kılınç, hulk ve ahlak göstergelerinden sadece k1lık göstergesine rastlanırken Kıssasü'l Enbiya'da (Telif tarihi: 14. yy, bk. Ata, 1997) kılık/k1lı̀ ile birlikte hulk göstergesi de göze çarpmaktadır.

Yine bu sahada da huy, mizaç/mezac, tab', tabiat göstergeleri k1lık/kılıg , kılınç, hulk ve ahlak göstergelerinin kavramsal eşdeğerleri olarak öne çıkmaktadır (bk. Ünlü, 2012b).

Orta Türkçenin kuzey kolunu teşkil eden Kıpçakçada kılınç dışındaki diğer üç gösterge de (kılık, hulk, ahlak) yer almaktadır. Et-Tuhfetü'z-Zekiyye Fi'lLügati't-Türkiyye'den tanıklanan kılğı (ahlak, huy) ile mizaç, tab', tabiat gibi göstergeler de diğer ahlak göstergeleri olarak kendini göstermektedir. Hemen her sahada hulk ve ahlak'la birlikte kullanılan hû/huy sözüne ise Kıpçak Türkçesi Sözlüğü'nde rastlanmamaktadır (bk. Toparlı vd., 2003).

Orta Türkçenin batı kolunu, Eski Anadolu Türkçesi (Eski Oğuzca) temsil etmektedir. Eski Anadolu Türkçesinde, Eski Türkçede ve Karahanlı sahasında kullanılan kılık ve kılınç göstergelerinin yanı sıra hulk ve ahlak göstergeleri de söz varlığına katılmış durumdadır.

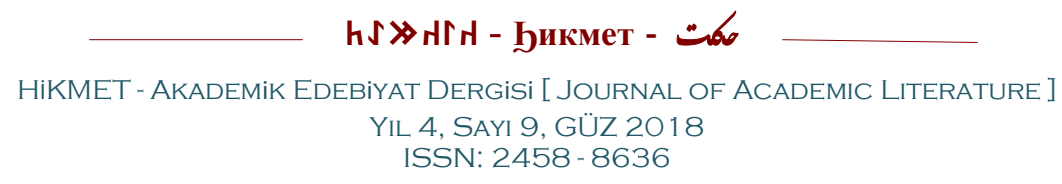


Söz konusu göstergelerin Eski Anadolu Türkçesindeki kullanım sıklığına dair kabaca bir tespit için dönemin başlıca eserlerinden birkaçına bakıldığında ${ }^{17}$ şu tablo ile karşılaşılmaktadır:

Tablo 1: Eski Anadolu Türkçesinde k1lık, k1lınç, hulk ve ahlak göstergelerinin kullanım sıklığı

\begin{tabular}{|l|l|l|l|l|}
\hline Eserler & kılık & kılınç & hulk & ahlak \\
\hline $\begin{array}{l}\text { Garib-nâme (Müellifi: Âşık Paşa, telif tarihi: } \\
\text { 14. yy., bk. Yavuz, 2000) }\end{array}$ & 3 & 59 & $1^{18}$ \\
\hline $\begin{array}{l}\text { Kitab-1 Gunya (Müellifi: İmâm Kâdî, telif } \\
\text { tarihi: 14. yy., bk. Muzaffer Akkuş, 1995) }\end{array}$ & - & - & - & - \\
\hline $\begin{array}{l}\text { Yunus Emre Divanı (Telif tarihi: 14. yy., bk. } \\
\text { Tatçı, t.y.) }\end{array}$ & - & 4 & 8 & - \\
\hline $\begin{array}{l}\text { Yunus Emre Divanı (Telif tarihi: 14. yy., bk. } \\
\text { Tatçı, t.y.) }\end{array}$ & - & - & 3 & 1 \\
\hline $\begin{array}{l}\text { Dede Korkut (Yazıya geçirilme tarihi: 15-16. } \\
\text { yy.? bk., Ergin, 1997) }\end{array}$ & - & - & - & - \\
\hline
\end{tabular}

Görüldüğü üzere, kılık, dört eserde de geçmemektedir. Ancak Tarama Sözlüğü'ne bakıldığında kılık (hal ü şan, hareket tarzı, gidiş) ${ }^{19}$ göstergesinin dönemin bazı eserlerinde kullanıldığı anlaşılmaktadır. Örneğin, şu kullanımlar, XIV. yy. eserlerinden Hurşid ü Ferahşad'dan (Müellifi: Germiyanlı Şeyhoğlu Mustafa Cemali) alıntıdır:

"Ne köp yahşi hamiyyet kuldınız siz

Yaman gönlüm kılı̆̆ın bildiniz siz (Hurşid ü Ferahşad, XIV. 56)

Alır ola cihanın alığını (alık: gidiş tarzı, gidişat)

Bilir ola zamanın kılı̆̆ını (Hurşid ü Ferahşad, XIV. 57)” (Tarama Sözlüğü, IV).

Aşağıdaki mısralar da kılınç, hulk ve ahlak göstergelerinin kullanımlarına dair örneklerdir:

Böyle şîrîn kulıncıla her kancaru bakarısam

Yitmiş iki milletine geçüriserdi sözini

Gözüm anun yüzinden niçe gideribilem

\footnotetext{
${ }^{17}$ Veriler; Garib-nâme ve Yunus Emre Divanı elektronik ortamda taranarak, diğgerlerininse dizinlerine bakılarak tespit edilmiştir.

18 Tespit edilen tek örnek, "Tahallakû bi-ahlâki'llâhi ta'âlâ" (Allahuteala'nın ahlakı ile ahlaklanın.) iktibasında geçmektedir. Dolayısıyla müellifin, ahlak göstergesini hiç kullanmadığı söylenebilir.

19 Metinlerde bir de başkasının hareket tarzını takınmak anlamında kılıklanmak fiiline rastlanmaktadır: Tetavvur (Ar.): Kılıklanmak (Bab. XVI. 2, 27); Teseyyür (Ar.): Kimsenin kılığı ile k1lıklanmak (Bab. XVI. 2, 27).
} 
Bin dürlü knlıncıla gönlümi şöyle kapdı

Hulkun olmayinca Muhammed gibi

Hak dîdârın sana göstermeye

Dil niçe vasf itsün hüsnünile hulkunı kim

Hüsnüni Hak eylesün yavuz gözlerden trak

Evvel bize vâcib budur hoş hulkıla 'amel gerek

İslâm adı okınıcak yoldaşumuz îmân gerek (Yunus Emre Divanı, Tatçı, t.y., 104, 110, 266, 293, 296 ).

lutf eyle 'aşıka vü gönüller ele getür

hulk $u$ vefâ gerek çü güzellik bekâ degül (Ahmed-i Dâi Divanı, Özmen, 2001: 154).

Ol ki yavuz hulkı terk itmez neçün

Biñ ögüt eydesin işitmez neçün

Ol dahı bayllk-durur bu dünyede

Diñle imdi ne makâmdur iy dede

Şoldur ol kim görklü hulk issi ola

Kime söylerse sözi ıssı ola (Garib-nâme, Yavuz, 2000: 89, 308)

Dil-ber oldur ki melâhatda latîf ola dahı 139).

Sureti gökçek ü hoşsîreti vü ahlâkı (Ahmed-i Dâî Divanı, Özmen, 2001:

Mehmet Kanar tarafindan hazırlanmış olan Eski Anadolu Türkçesi Sözlüğü'nde bu verilerden daha farklı bir manzara göze çarpmaktadır. Zira hulk eylemek (iyi davranmak, yumuşak davranmak), hulk itmek (iyi davranmak, yumuşak davranmak, alttan almak) ve hulkı dar (tahammülsüz) gibi sözler eserde madde başı olarak mevcut bulunmasına rağmen (bk. 2011: 356), hulk sözü madde başı olarak yer almamaktadır. Yine, Eski Anadolu Türkçesinde, seyrek de olsa, kullanımına rastlanan ahlak sözü de madde başı olarak sözlükte geçmemektedir.

Hiç şüphesiz Eski Anadolu Türkçesinde ahlak sözleri anılanlardan ibaret değildir. Huy, mizaç, tab ${ }^{`}$, tabiat gibi sözler de ahlak kavramını karşılamak için sıklıkla kullanılmıştır (bk. Yavuz, 2000; Tatçı, t.y.). Yine, erdem, görklülük, fazilet, hilm, sabır, yavaşlık; fısk, yavuzluk, yalancılık, yatlug (kötülük, fenalık) gibi güzel ve kötü ahlaki özellikleri karşılayan sözler de burada sayamayacağımız çokluktadır. Aynı örnekler, Eski Anadolu Türkçesinin devamı olan Osmanlı Türkçesinde de geçtiğinden kapsamlı örneklendirme orada yapılacaktır.

Kılık, kılınç, hulk ve ahlak kavramları ile eş anlamlı olarak metinlerde sıklıkla geçtiği için, hu/huy (Fars. hū̄y) göstergesinin kullanımı da aşağıda örneklendirilmiştir:

Yohsa ger hayvân husiysa hû saña

Âdem-iken hayvân olduñ yû saña

h $\ \gg$ तin - Ђикмет - ت 
Vây eger dutduñ-ısa hulk-ı nebât

Çün ölesin ummagll ayruk hayât

Tañrl sevmez bu hulu 'avratlart

Oldur âhir Tañrı'nuñ âfetleri

Ol kılınç hôd kamuya lâyık degül

Hak anı sevmeklige bayık degül (Garib-nâme, Yavuz, 2000: 127, 465)

Bütün bu veriler değerlendirildiğinde şu sonuçlara ulaşmak mümkündür:

1. Orta Türkçenin doğu kolunu teşkil eden Karahanlı döneminde hulk ve ahlak göstergelerine rastlanmamaktadır. Eski Türkçede olduğu gibi bu dönemde de ahlak kavramını karşılamak üzere yine yaygın olarak kılk/kılık, kılınç göstergeleri kullanılmıştır.

2. Karahanlı Türkçesinin devamı olan Harezm Türkçesi ve dönemin kuzey kolunu teşkil eden Kıpçak Türkçesinde kılınç'a göre kılık göstergesinin daha yaygın kullanıldığı, kılık göstergesinin yanı sıra yer yer hulk ve ahlak göstergelerine de rastlandığg söylenebilir. şöyledir:

3. Dönemin batı kolunu teşkil eden Eski Anadolu Türkçesinde ise durum

a. Ahlak kavramına karşılık yaygın olarak hulk göstergesi kullanılmıştır.

b. Ahlak göstergesinin kullanımı henüz yaygın değildir.

c. Eski ve Orta Türkçede ahlak kavramına karşılık olarak kullanılan kılık ve kılınç göstergelerinin kullanımı iyice seyrekleşmiş durumdadır.

\section{Yeni Türkçede (YT'nin 3. Döneminde)}

Yeni Türkçe Dönemi Türk dilinin 16 ile 20. yüzyıllar arasındaki dönemidir. Batıda Osmanlıca, doğuda Çağatayca bu dönemin başlıca yazı dilleridir (Özyetgin, 2006).

Çağatay Türkçesi Sözlüğü'nde k1lık, ķılığ, hulk, ahlak göstergeleri ile onların kavramsal eşdeğeri olan hû, hûy, mizaç, tab', tabiat göstergelerinin kullanıldığı tespit edilmiştir. Sözlükte kılınç göstergesinin yer almaması dikkat çekicidir (bk. Ünlü, 2013).

Eski Anadolu Türkçesi ile Çağdaş Türkiye Türkçesi arasındaki halkayı oluşturan Osmanlı Türkçesine gelince; bu dönemin başlıca sözlüklerinde ahlak kavramına karşılık olarak kılık, kılınç göstergelerine rastlanmamaktadır (Şemsettin Sami, t.y.; Devellioğlu, 1988; Kartal, 2009; Tulum, 2011). Tarama Sözlüğü, k1lık göstergesinin 16. yy.da kullanıldığına dair Babus-ül Vâsıt'tan (Arapçadan Türkçeye Sözlük, Müellifi: Musa Merkez Efendi Oğlu Mehmet, Telif tarihi: XVI. yy.) birkaç örnek gösterse de yaptığımız şu tarama Osmanlı Türkçesinde kılık ve kılınç göstergelerinin hulk/ahlak kavramına karşılık kullanıldığına dair bir veri sunmamaktadır:

Tablo 2: Osmanlı Türkçesinde kılık, kılınç, hulk ve ahlak göstergelerinin kullanım sıklı̆ 1 


\begin{tabular}{|l|l|l|l|l|}
\hline Eserler & kılık & kılınç & hulk & ahlak \\
\hline $\begin{array}{l}\text { Baki Divanı (Telif tarihi: 16. yy., bk. Küçük, } \\
\text { t.y.) }\end{array}$ & - & - & 11 & - \\
\hline $\begin{array}{l}\text { Nefi Dîvânı (Telif tarihi: 17. yy., bk. Metin } \\
\text { Akkuş, 2018)) }\end{array}$ & - & - & 54 & 7 \\
\hline $\begin{array}{l}\text { Hayriyye [Müellifi: Nabi, telif tarihi: 18. yy. } \\
\text { (1701), bk. Kaplan, 1990]. }\end{array}$ & - & - & 7 & 3 \\
\hline $\begin{array}{l}\text { Lebib Divanı (Telif tarihi: 18. yy., bk. } \\
\text { Kurtoğlu, 2017) }\end{array}$ & - & - & 19 & 25 \\
\hline $\begin{array}{l}\text { Mihnetkeşan (Müellifi: Keçecizâde İzzet } \\
\text { Molla, telif tarihi: 19. yy., bk. Özyıldırım, t.y.) }\end{array}$ & - & - & 3 & 3 \\
\hline
\end{tabular}

Bu bilgilere göre Eski Anadolu Türkçesinde kullanımına rastlanan kılık ve kılınç sözlerinin Osmanlı Türkçesinde hemen hemen kullanımdan düştüğü, yine o dönemde henüz kullanılmaya başlanan ahlak göstergesinin eser adlarına taşınarak ${ }^{20}$ hulk göstergesi ile yakın bir kullanım sıklığına ulaştığı anlaşılmaktadır. Metinlerde ahlak çevresinde oluşan ilm-i ahlak, mehâsin-i ahlâk, mekârimü'l-ahlâk, tehzib-i ahlak, ahlâk-1 hasene, ahlâk-1 hamide; sû-i ahlak, ahlâku'z-zemîme, ahlâk-1 seyyie gibi tamlamalar da ahlak göstergesinin dile iyice yerleştĭgini açıklar niteliktedir.

Taranan eserlerden hulk ve ahlak göstergelerinin geçtiği bazı beyitler aşağıda sunulmuştur:

Ne şeh İskender-i devrân ki Eflâtûn eger görse

Olur bin cân ile meftûn-ı hüsn-i hulk u etvârı

Emel vezâyif-i cûduyla kâmrân u ganî

Kerem letâif-i hulkuyla hande-rûy u besîm

Hüsn-i ahlâkı yerinde harekâtı mevzûn

Şîvesi cilvesi hep biribirinden alâ

Ger olsa nükhet-i ahlâkı gülde tesiri

Ederdi dûd-ı buhûr âh-ı andelîbânı (Nefi Dîvânı, bk. Metin Akkuş, 2018: 65-127).

\section{Ricâl-i saltanatın ekserisi bendesidir}

Cihânı etse revâ hüsn-i hulku ile esîr

Edip bend zencîr-i ahlâk ile

\footnotetext{
${ }^{20}$ Eski Anadolu Türkçesinde kullanımına nadiren rastlanan ahlak göstergesinin Osmanlı Türkçesinde bu denli yaygınlaşmasının en önemli sebebi olarak onun zaman içinde eser adlarına taşınmış olması sayılabilir. Hiç şüphesiz bu eserlerin başında da geniş kitlelerce benimsenip okunan Ahlâk-1 Alâî gelmektedir. 16. yy.da Kınalızâde Ali Çelebi tarafından Türkçe olarak kaleme alınan eser, kendinden sonraki birçok ahlak kitabına kaynaklık etmiş, son dönemlere kadar Osmanlı mekteplerinde okutulmuştur (Kahraman, 1989; Levend, 1963).
} 
Kul etdi beni birr ü eşfâk ile

Maârifde meşhûr-ı âfâk ise

Hünerver denilmez bed-ahlâk ise (Mihnetkeşan, bk. Özyıldırım, t.y., s.286, $380)$.

Şümâr-ı hüsn-i hulkun hâric-i tavk-ı beşer buldum4

Meger emvâc-ı bahri kimse var mı eylemiş ihsâ

Bilmem Ahlâk-ı 'Alâ' î nüsha-i zâtın mıdır

Kim cihâna hüsn-i ahlâkın nümâyân eyledi (Lebib Divanı, bk. Kurtoğlu, 2017: 116, 122).

Türklerin İslamiyet'le tanışması ile birlikte İslam kültürünün en önemli değerlerinden olan insan-1 kâmil ideali, fütüvvet ${ }^{21}$ kitapları ve pendnameler/nasihatnameler başta olmak üzere çeşitli dini-tasavvufi eserlerde çokça işlenmiş, zaman içinde gerek ahlak kavramına eşdeğer gerekse iyi ve kötü ahlaki özellikleri belirten çok sayıda unsur söz varlığına katılmıştır. Bu unsurlar Osmanlı Türkçesinde bir lügatçe oluşturacak niceliktedir. Söz konusu unsurlardan bazı örnekler aşağıda sunulmuştur ${ }^{22}$ :

\section{unsurlar:}

Anlamı veya anlamlarından biri hulk ve ahlak sözleri ile eşdeğer

âdet (a.i.c.: âdât): görenek, usul, tabîat, alışkanlık.

âmîziş (f.i.): geçiniş, uysallık, (bkz: imtizaç).

bûm (f.i.): 1. yer, toprak, yurt. 2. sürülmemiş tarla. 3. tabiat, huy.

cibillet (a.i.): huy, cibilliyet, yaradılış. (bkz: fitrat).

ciriyyâ (a.i.): 1. tabîat, mizaç. 2. âdet, alışkanlık.

fitrat (a.i.): yaradılış, tabîat, mizaç, huy. (bkz: seciyye, tînet).

garîze (a.i.): 1. tabiî sevk, içgüdü. 2. huy, tabiat, fr. instinct. (bkz: cibillet).

haslet (a. i. c.: hısâl): insanın yaradılışındaki huyu, tabiatı, mizacı.

hicîr (a.i.): huy, âdet, tabiat.

hîm (a.i.): huy, tabiat.

hûy, hû (f.i.): tabiat, mizaç, ahlâk; âdet.

meniş (f.i.): huy, tabiat.

meşreb (a.i.c.: meşârîb): 1. içecek yer. 2. yaradılış, tabîat, mizaç; huy, ahlâk.

${ }^{21}$ Uludağ (1996), fütüvvet kavramına şöyle açıklık getirmiştir: "Fetâ sözlükte 'genç, yiğit, cömert'; fütüvvet ise 'gençlik, kahramanlık, cömertlik' anlamlarına gelir. (...)Genel olarak fetâ ve fütüvvet kelimeleri sûfì ve tasavvuf anlaminda kullanılmakla beraber tasavvufta bu terimlerden çok defa sûfîde bulunan fedakârlık, diğergâmlık, iyilik, yardım, insan severlik, hoşgörü ve nefsine söz geçirme gibi ahlâkî nitelikler kastedilir. Böylece gerçek yiğitlik, kahramanlık, cesaret ve mertliğin bu ve benzeri niteliklere sahip olmayı gerektirdiği anlatılmak istenir. Bu husus dikkate alındığında sûfilerin kendilerine has hümanizm düşüncelerini fütüvvet kavramı çerçevesinde geliştirdikleri görülür"

22 Örnekler, Devellioğlu'nun (1988). Osmanlıca-Türkçe Lûgat'inde yapılan yüzeysel bir taramadan elde edilmiştir. Gerektiğinde bazı açıklamalarda kısaltmaya gidilmiştir. 
mizaç (a.i. mezc'den. c.: emzice): 1. bir şeyle kanştınlmış olan başka şey. 2 . huy, tabîat. 3. sihhat seciyye (a.i.c.: secâyâ) huy, tabîat, karakter (bkz: meşreb).

nahîle (a.i.): huy, tabîat.

nihâd (f.i.): 1. tabîat, huy. yaradılış.

pîşe (f.i.c.: pîşe-gân): 1. san'at, meslek. (bkz : hirfet). 2. iş. (bkz: amel). 3. huy, tabîat, âdet, alışkanlık.

seciyye (a.i.c.: secâyâ): huy, tabîat, karakter (bkz: meşreb).

sîret (a.i.c.: siyer): 1. bir kimsenin içi, hâli, tavrı, gidişi, ahlâkı. 2. hal tercümesi, fr. biographie.

sirişt (f.i.): yaradılış, tabiat, huy. (bkz: hilkat, tabîat).

sûs (a.i.): 1. tabiat, huy. (bkz: tînet). 2. meyan kökü.

sünnet (a.i.c.: sünen): 1. iyi ahlâk, iyi tabîat.

şâkile (a.i.c.: şevâkil): 1. yol, tarîk, mezhep, meslek. 2. yaradılış, (bkz: tıynet).

şemâil (a.i. şimâl'in c.): 1. huylar, tabîatler, ahlâklar.

şîme (A.i.c.: şiyem): huy, tabîat. (bkz: haslet).

tab' (a.i.): 1. tabiat, huy, yaradı1ış. 2. mühür, damga basma. 3. kitap basma.

tabîat (a.i.c.: tabâi'): 1. tabîat, yaradılış, huy, âdet, mizaç.

tıynet (a.i.): yaradılış, mizaç, maya...

\section{işaret eden unsurlar:}

adâlet-kâr (a.f.b.s.): âdil, adaletli, (bkz: adâlet-penâh).

âlî-cenâb (a.b.s.): 1. cömert. 2. şerefli, haysiyetli kimse.

âzerm-cû (f.b.s.): terbiyeli, nâzik.

edîb, edîbe (a.s. edeb'den): 1. edepli, terbiyeli, zarif, nâzik [kimse].

ekrem (a.s.): 1. daha (en, pek) kerîm; çok şeref sahibi, pek cömert, çok eli açık.

erbâb-1 tab': tabiat sahipleri, iyi yaratılıştı kimseler.

erbâb-1 namus: namuslular.

ercmend (f.s.) 1. muhterem, şerefli, itibarl1, haysiyetli, seçkin.

fâzıl (a.s.c.: fuzalâ): 1. faziletli, fazilet sahibi, erdemli; faik, üstün.

firişte-hû, firişte-haslet (f.a.b.s.): huy ve tabîatçe melek gibi olan. (bkz: firişte-sıfat).

gazîr, gazîre (a.s.): yumuşak, mülayim, tatl1, nâzik, uysal.

hâkî-nihâd (f.b.s.): mütevâzi, alçakgönüllü.

halîm (a.s.): 1. tabiatı yavaş olan, yumuşak huylu. [Allah adlarındandır].

\section{hЈ»hז - நикмет -}

HIKMET - AKADEMIK EDEBIYAT DERGISi [ JOURNAL OF ACADEMIC LITERATURE ] 
hoş-meniş (f.b.s.): huyu, tabîatı iyi. (bkz: hoş-tab').

hoş-meşreb (f.a.b.s.): huyu güzel, sevimli.

hoş-tab' (f.a.b.s.): tabiat1, huyu güzel.

kâmil (a.s. kemâl'den): 1. bütün, tam, noksansız eksiksiz. 2. kemâle ermiş, olgun. 3. yaşını başını almış, terbiyeli, görgülü, pişmiş [kimse]. 4. âlim, bilgin, geniş bilgili [kimse].

kibar (a.s. kebîr'in c.): 1. büyükler, ulular. 2. ince, terbiyeli, görgülü, nâzik.

lâtif (a.s.): 1. Allah adlarındandır. 2. yumuşak, hoş, güzel; nâzik.

leyyinü'1-cânîb: yumuşak tabiatlı, kanı sıcak kimse.

müeddeb (a.s. edeb'den): 1. te'dîb edilmiş, edeplendirilmiş, edepli, terbiyeli.

müşfik (a.s. şefakat'den): şefkatli, merhametli, acıyan; seven.

mütevazı' (a.s. vaz'dan. c.: müte-vâzî̂n): 1. tevazu eden, alçakgönüllü, kibirsiz. 2. gösterişsiz.

müttaki (a.s. vaky ve vikaye'den): 1. ittika eden, sakınan, çekinen. 2 . Allah'tan korkan, (bkz: âbid, zâhid).

nâzik-hulk (f.a.b.s.): tabiatı, yaradılışı nâzik olan.

nâzik-mizâc (f.a.b.s.): nâzik tabîatlı.

nîk-haslet (f.a.b.s.): ahlâkı, huyu iyi olan.

nîk-hû (f.b.s.): iyi huylu, huyu güzel.

perniyân-hû[y] (f.b.s.): güzel, nâzik huylu.

râd (f.s.): 1. cömert, eli açı. (bkz: sahî). 2. faziletli, erdemli, üstün, değerli.

sabbâr (a.s.): çok sabırlı, sabrı çok olan. (bkz: sabûr).

sahâ-kâr (a.f.b.s.): cömert, eli açık. (bkz. sahî).

sâlih, sâliha (a.s. salâh'den. c.: sâlihûn, sulehâ): 1. yarar, elverişli, iyi, uygun, yakışır. 2. salâhiyeti (yetkisi) ve hakkı olan. 3. dînin emrettiği şeylere uygun harekette bulunan.

selîm-ül-kalb temiz yürekli adam.

şerif (a. s. şeref den. c.: eşrâf): 1. şerefli, mübarek, kutsal. 2. soylu, temiz.

tıynet-i pâk: temiz yaradılış; saf tabiat...

\section{unsurlar:}

Su-i hulk/ su-i ahlak sahibi nâkıs insan tipinin özelliklerine işaret eden

âsî (a.s.): ahlâkı bozuk, ahlâksız, çapkın.

âteş-mizâc (f.b.s.): sert tabiatlı, huysuz, geçimsiz [kimse].

bed-güher [gevher] (f.b.s.): içi, tabiatı fena, soysuz, mayası bozuk.

bed-mâye (f.b.s.): soysuz, sütü bozuk.

bed-meniş (f.b.s.): kötü huylu, kötü tabiatlı.

hJ》h厂n - Ђикмет -

HIKMET - AKADEMIK EDEBIYAT DERGISi [ JOURNAL OF ACADEMIC LITERATURE ] 
bed-reg (f.b.s.): huysuz, damarsiz.

bed-sîyret (f.a.b.s.): kötü huylu, ahlâksız.

bed-tıynet (f.a.b.s.): yaratılışı, tabiatı fena olan, soyu bozuk, bayağı adam. (bkz. bed-sîret).

bed-üslûb (f.a.b.s.): tavrı, gidişi kötü.

bî-edeb (f.a.b.s.): edepsiz, terbiyesiz.

cafcaf (f.s.): iffetsiz, ahlâksız [kadın], yırtlaz. (bkz. cefcâf).

cahûf (a.s.): kendini beğenmiş, kibirli. (bkz. mağrur).

celbiz (f.i.): 1. kement, ilmik. 2. s. ara bozucu, koğucu. (bkz. gammaz).

cilf (a.s.): kaba, hoyrat; ayak takımından.

demevi-yy-ül-mizâc: tabiatı demevî olan, asabî, sinirli.

denâet-kâr (a.f.b.s.): denî ve alçak tabiatlı.

ebü-l-iber (abs): edebpsiz utanmaz (adam).

efsak (a.s.): en fâsık, pek edepsiz.

erzel (a.s. rezîl'den): 1. alçak, soysuz. 2. daha [en, pek, çok) rezil.

ez'ar (a.s.): gaddar ve zâlim [adam].

fâcir, fâcire (a.s. fücûr'dan. c.: fecere, füccâr): 1. fücur sahibi, fena huylu, günahkâr. 2. ayyaş, sefih. 3. habîs; rezîl; şerir; şakî. 4. yalancı. 5. kadına düşkün erkek, erkeğe düşkün kadın.

fahhâş (a.s.): her türlü kötülükleri şahsında toplamış [kimse].

fahiş (a.s. fahş'dan): 1. mübalâğalı, taşkın, aşın. 2. büyük, iri. 3. ahlâksız, ahlâka aykırı; çirkin, pek kötü.

fâsık (a.s. fisk'dan. c.: feseka, füssak): Allah'ın emirlerini tanımayan, sapkın, günah işleyen, fesatçı, kötülük eden.

gammâz (a.s. gamz'dan): birine, iftira ederek zarar veren, münafik, fitneci, koğucu.

gâv-meşreb (f.a.b.s.): öküz tabiatlı.

gerdenferâz (f.b.s): mağrur.

gerdûn-sirişt (f.b.i.) 1. kibirli, gururlu [kimse]. 2. tembel. 3. kan dökücü, zâlim, (bkz. hûn-seffâh, seffâk).

gırra (a.s.) gururlu, kibirli, kendini beğenmiş [kimse], (bkz: mağrûr).

gürdâs (f.s.) zâlim, gaddar, (bkz: bî-dâd, gaşûm.

güstâh (f.s.) küstah, hayâsız, arsız, edepsiz, saygısız.

hadîd-ül-mizâc: sert tabiatlı, asabî.

halî-ül-izâr (a.b.s.) (yüzü yırtık) sıyrık, edepsiz, alnının damarı çatlamış, (bkz: fersûde-pîşânî).

hâne ber-dûş (f.b.s.): (evi omzunda) serseri.

hJ》h厂n - Ђикмет -

HIKMET - AKADEMIK EDEBIYAT DERGISi [ JOURNAL OF ACADEMIC LITERATURE ] 
harîs (a.s. hırs'dan): hırslı, tamahkâr, bir şeye çok düşkün, lüzumundan fazla istekli.

har-meniş (f.b.s.): eşek tabiatlı.

hôd-bîn (f.b.s.): kendini beğenmiş, bencil, (bkz: mağrûr, mütekebbir).

hôd-bîn (f.b.s.): kendini beğenmiş, bencil, (bkz: mağrûr, mütekebbir).

hôd-endîş (f.b.s.): kendini düşünen. ârâ).

hôd-fürûş (f.b.s.): kendini satan, kendini medheden, övüngen. (bkz: hôd-

hôd-pesend (f.b.s.): kendini beğenen, (bkz: hôd-gâm, hôd-perest, hôd-sitâ).

kec-mizac (f.a.b.s.): Mizac1, tabiatı hoş olmayan. (bkz: kec-tab).

kezzâb (a.s. kizb'den): çok yalan söyleyen, pek yalancı.

mağrur (a.s. gurûr'dan): 1. gururlu. 2. bir şeye güvenen 3. güvenilmeyecek şeye güvenip aldanan, kendini beğenmiş [kimse]. 4. büyüklük taslayan, (bkz. girra, müteazzım, mütekebbir).

muhannes (a.s.): korkak, alçak, kadın tabiatl1, kalleş, (bkz: nâ-merd).

münafik (a.s. nifâk'dan. c.: münâfikîn): 1. nifak sokan, ikiyüzlülük eden, iki yüzlü, (bkz: mürâî).

mütehettik (a.s. hetk'den): 1. tehettük eden, yırtılan. 2. utanmaz, edepsiz, yirtık.

nemîme-kâr (f.b.s.): koğucu, münafik, arabozan, (bkz: nemmâl, nemmâm, nemmâs, zemmâm).

riyakâr (a.f.b.s.): ikiyüzlü.

sâlûs (f.s.): riyakâr, ikiyüzlü, (bkz: münafik, zerrâk).

sitem-ger (f.b.s.c.: sitem-gerân): zulmeden, haksızlık eden; zâlim, (bkz: sitem-gâr, sitemkâr).

siyeh-kâr (f.b.s.): kötü işler yapan, günaha giren, (bkz: fâsık, siyâh-kâr).

tünd-meşreb (f.b.s.): sert tabiatlı, titiz, (bkz: tünd-hû[y], tünd-mizâc).

vakih (a.s.): edepsiz, hayâsız, utanmaz.

zâlim, zâlime (a.s. zulm'den. c.: zaleme, zâlimîn, zâlimûn): zulmeden, haksızlık eden... (bkz: sitem-kâr). (Devellioğlu, 1988).

Buraya kadar sunulan ahlak sözleri, genel olarak Türkçe, Arapça, Farsça kökenli idi. Peki bugün okullarda ders olarak okutulmaya başlanan, adına sempozyumlar düzenlenen ve akademik çevrelerde kullanım sıklığı açısından yer yer ahlak göstergesinin önüne geçen Batı kökenli etik göstergesi Osmanlı Türkçesinde yerini almış mıdır?

Osmanlının son döneminde, Tanzimat'la birlikte özellikle bir kısım aydınlar üzerinden Batı kültürüne bir yönelmenin olduğu bilinmektedir. Ancak aynı nispette o dönemde dilde ve kültürde bir millileşme/yerlileşme düşüncesi de söz konusu olup daha baskın bir keyfiyettedir. Dolayısıyla Batı'dan alıntı sözler

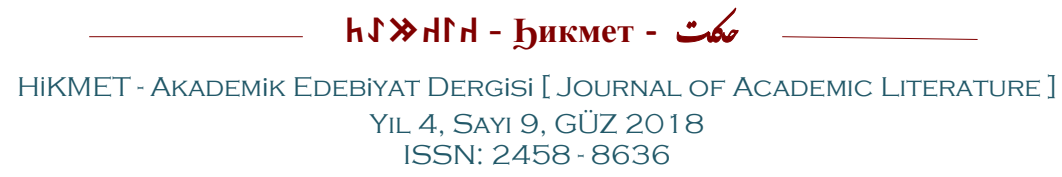


henüz sınırlı sayıdadır ve az bir kısmı genel Osmanlıca sözlüklere girebilmiştir. Etik göstergesinin o dönemde bir kısım çevrelerde kullanılıp kullanılmadı̆̆ 1 bizce meçhuldür. Ancak Osmanlı Türkçesinin önemli sözlüklerinde henüz yer almadığ 1 açıktır [bk. Kâmus-1 Türkî (Şemsettin Sami, t.y. ${ }^{23}$ ); Lügat-i Nâcî (Kartal, 2009); Lügat-i Cûdî (Parlatır vd., 2006)].

\section{Modern Türkçede (YT'nin 4. Döneminde)}

Türk dili devirlerinin tasnifinde 20. yy. ve sonrası yaygın olarak Modern Türkçe Dönemi olarak adlandırılır. Dolayısıyla Modern Türkçe, Türkçenin bugünkü canlı lehçelerini kapsamaktadır (Özyetgin, 2006).

Çalışmamızın sınırı gereği, konu Modern Türkiye Türkçesi çerçevesinde sürdürülecektir. Öncelikle Türk Dil Kurumunun Güncel Türkçe Sözlük'ünü esas alarak daha önceki devirlerde ahlak kavramına karşıllı olarak kullanılan kılık, kılınç ve hulk sözlerinin aynı anlamları ile Modern Türkiye Türkçesindeki kullanılıp kullanılmadıklarına bakalım:

\section{Kılık:}

"kllık-ğg isim: 1. isim Bir kimsenin giyinişi, dış görünüşü, üst baş

"Delikanlı kopuklar, kllılarından, giyinişlerinden belli oluyorlar." - M. Ş. Esendal

\section{Bir kimsenin resmi, fotoğraf",}

Kilınç: Sözlükte yok.

Hulk: Sözlükte yok.

$\mathrm{Bu}$ verilere göre, zaman zaman kullanım sıklıkları değişse de, yüzyıllarca ahlak kavramına karşılık olarak kullanılan kılınç ve hulk sözleri Modern Türkiye Türkçesinde kullanımdan düşmüş görünmektedir ${ }^{24}$. Kılık sözü, ise anlamsal bir değişimle soyuttan somuta geçmiş durumdadır.

Söz konusu göstergeler yerine, Modern Türkiye Türkçesinde ahlak'a artık daha çok Batı'dan alıntı etik göstergesi eşlik etmektedir. Yine akademik ortamlar başta olmak üzere, kimi çevrelerde yer yer moral'in de ahlak'a karşıllık olarak kullanıldığı görülmektedir. Peki, etik ve moral'in genel Türkçe sözlüklerde yer bulması hangi zamana tekabül etmektedir? Bu sorunun cevabı aşağıdaki tablodadır:

\footnotetext{
${ }^{23}$ Telif tarihi: 1900.

24200 öğrenciye yönelik yaptığımız küçük çaplı anketin sonuçları da hulk'un ahlak'la ilgisinin unutulduğunu, dolayısıyla kullanım dışı kaldığını ortaya koyar niteliktedir. Zira 200 katılımcıdan 68 'i (\% 34) hulk sözüne herhangi bir anlam verememiş, 101(\% 50.5)'i hulk sözünü doğrudan veya dolaylı olarak hayali film kahramanı Hulk ile ilişkilendirmiş (Cevaplardan bazıları şöyledir: çizgi film kahramanı, yeşil adam, yeşil dev, güçlü kuvvetli, canavar, sinema karakteri...), 31 (\% 15.5)'i ise hulk'a şu tür farklı karşılıklar vermişlerdir: hukuk, halk'ın eski Türkçesi, helak, halık (yaratıcl, ilah), sulh, topluluk, yaratmak (yaratan, yaratıcl), bir futbolcu adl...
}

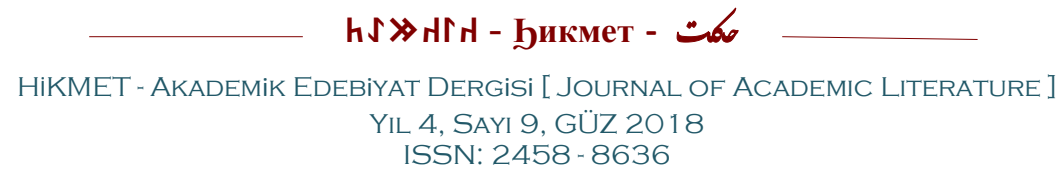


Tablo 3: Türkçe sözlüklerde etik ve moral sözcüklerinin yer alma zamanı

\begin{tabular}{|c|c|c|c|c|c|}
\hline & $\begin{array}{l}\text { Türkçe } \\
\text { Sözlük } \\
1944\end{array}$ & $\begin{array}{l}\text { Türkçe } \\
\text { Sözlük } \\
1959\end{array}$ & $\begin{array}{l}\text { Türkçe } \\
\text { Sözlük } \\
1974\end{array}$ & $\begin{array}{l}\text { Türkçe } \\
\text { Sözlük } \\
1983\end{array}$ & $\begin{array}{l}\text { Türkçe Sözlük } \\
1998\end{array}$ \\
\hline Etik: & - & - & - & $\begin{array}{l}+ \\
\text { a. Yun.> Fr. } \\
\text { Y-törebilim, } \\
\text { ahlakbilim }\end{array}$ & $\begin{array}{l}+ \\
\text { İs. Fr. etique 1. töre } \\
\text { bilimi, } 2 \text {. ahlakî, } \\
\text { ahlakla ilgili }\end{array}$ \\
\hline Moral: & - & - & $\begin{array}{l}\text { + ruhsal } \\
\text { güç }\end{array}$ & & $\begin{array}{l}+ \\
\text { is. bir insanın } \\
\text { ruhsal gücü, yürek } \\
\text { gücü, maneviyat }\end{array}$ \\
\hline Moralizm: & - & $\begin{array}{l}+ \\
\text { törecilik }\end{array}$ & & & $\begin{array}{l}+ \\
\text { ahlakçılık doktrini, } \\
\text { ahlakı araç değil, } \\
\text { amaç sayan doktrin, } \\
\text { törelcilik }\end{array}$ \\
\hline
\end{tabular}

Görüldüğü üzere, Türkçe Sözlük’e önce moralizm (1959), sonra moral (1974) daha sonra etik (1983) girmiştir. Dolayısıyla bu bilgilere göre, etik'in Türk Dil Kurumunun genel Türkçe sözlüklerinde madde baş1 olarak yerini bulması 1980'den sonradır.

Yine Batı'dan alınma karakter (Fr. caractère $<$ Lat. $<$ Yun.) ve Doğu'dan alınma huy (Fars. hū̄y), mizaç (Ar. mizāc), seciye (Ar. seciyye), tabiat (Ar. țabiat), adet (Ar. 'ādet) gibi göstergeler de Modern Türkiye Türkçesinde ahlak'ın müteradifleri olarak öne çıkmaktadır.

Dil Devrimi'ni müteakip, önerilen töre (örf, adet, ahlak) eksenli öz Türkçe şu ahlak sözlerinin kullanımı ise yeterince yaygınlaşmamıştır:

töre, aktöre, să̆töre, alışk: ahlak,

törel, törebilim: etik,

törel bilinç: vicdan,

sağtöresel/aktörel: ahlaki,

törebilmez: karaktersiz,

aktöredışı /töredışı: amoral, gayri ahlaki,

töreye aykırı: gayrı meşru (Türk Dil Kurumu, 1978; Ünlü, 1977; Püsküllüoğlu,1994).

Buraya kadar Eski Türkçeden Modern Türkçeye değin Türkçede kullanılan başlıca ahlak sözleri ortaya konmaya çalıșıldı. Bunlardan ahlak kavramını birinci dereceden karşılayanlarını şöyle tablolaştırmak mümkündür: 
Tablo 4: Türkçe'de kullanılan başlıca ahlak sözleri

\begin{tabular}{|l|l|l|}
\hline \multicolumn{2}{|c|}{ Tarihi devirler ve sahalar } & Kullanılan ahlak sözleri \\
\hline \multicolumn{2}{|c|}{ Eski Türkçede } & ķ1lış, ķılınç \\
\hline \multirow{2}{*}{ Orta Türkçede } & Karahanlı Türkçesi & \\
\cline { 2 - 3 } & Harezm Türkçesi & k1lık/kılı̆̆, kılınç \\
\cline { 2 - 3 } & Kıpçak Türkçesi & k1lık/kılığ, kılınç, hulk, ahlak \\
\cline { 2 - 3 } & Eski Anadolu Türkçesi (Eski Oğuzca) & k1lık, k1lınç, hulk, ahlak \\
\hline \multirow{2}{*}{ Yeni Türkçede } & Çağatay Türkçesi & k1lık, ķ1lığ, hulk, ahlak \\
\cline { 2 - 3 } & Osmanlı Türkçesi & hulk, ahlak \\
\hline Modern Türkçede & Türkiye Türkçesi & ahlak, etik \\
\hline
\end{tabular}

\section{Ahlak ve etik göstergelerinin günümüz Türkçesindeki kullanım}

\section{keyfiyetleri}

Daha önceki bölümde ahlak ve etik göstergelerinin Türkçenin söz varlığına katılma süreçleri ve aynı kavram alanını paylaştıkları göstergeler üzerinde duruldu. $\mathrm{Bu}$ bölümde ise söz konusu göstergelerin Modern Türkçede hangi anlam ve bağlamlarda kullanıldıkları ele alınmaya çalışılacaktır. Bu arada sözlüksel verileri teyit için çalışmanın başında zikredilen anketin sonuçlarına da yer yer değinilecektir.

\section{2.a. Ahlak ve etik göstergelerinin kullanılış anlamları} bakalım:

Öncelikle Güncel Türkçe Sözlük'ün bu iki kavramı nasıl tanımladığına

\section{Ahlak}

isim (ahla:kl, lince okunur) Arapça ahlāk

1. isim Bir toplum içinde kişilerin uymak zorunda oldukları davranış biçimleri ve kurallarl, aktöre, sağtöre "Ahlak düzelmeden hiçbir şey düzelmez." Ç. Altan

2. Huylar

"Bu şoförler hepinizin ahlakını bozdu." - M. Ş. Esendal

etik- $\breve{g} i$

isim Fransizca éthique

1. isim Töre bilimi

2. Çeşitli meslek kolları arasında tarafların uyması veya kaçınması gereken davranışlar bütünü 


\section{Etik bilimi}

4. sıfat Ahlaki, ahlakla ilgili” (http://www.tdk.gov.tr/, erişim: 01.05.2018)

$\mathrm{Bu}$ açıklamalardan şu sonuçlara ulaşmak mümkündür: verilmiștir.

1. Ahlak'ın 1. anlamı, kurallar bütünü; etik'in, töre bilimi olarak

2. Ahlak için verilen iki anlam (1. ...davranış biçimleri, kuralları; 2 . Huylar) da çoğul isimdir. Buna karşın etik, 4. anlamı ile sıfattır.

3. Etik' in 1. anlamı (töre bilimi) ile 3. anlamı (etik bilimi) aynıdır.

4. Ahlak'ın 1. anlamı (Bir toplum içinde kişilerin uymak zorunda oldukları davranış biçimleri ve kuralları...) ile etik'in 2. anlamı (2. Çeşitli meslek kolları arasında tarafların uyması veya kaçınması gereken davranışlar bütünü) arasında belirgin bir fark bulunmamaktadır. Tek nüans, ahlak'ın daha geniş/genel (toplum içinde), etik'in daha dar/özel (çeşitli meslek kolları arasında) bir alanı işaretlemesidir. Yani bu tanıma göre ahlak, toplumsal; etik, mesleki kurallar manzumesidir.

$\mathrm{Bu}$ veriler değerlendirildiğinde, ahlak ve etik göstergelerinin kavramsal ayrımında bir bulanıklığın bulunduğu, verilen anlam tabakalarının, gerek sıralama gerek çerçeve açısından sorunlu olduğu açıktır. Zira sözlük türleri içerisinde bir dilin bütün konuşurlarını ilgilendirenler, yazı dili sözlükleri (genel sözlükler)dir. $\mathrm{Bu}$ sözlükler aynı gösterenden aynı şeyin anlaşılmasını sağlayarak toplumsal iletişimin tesisine yardımcı olur. Dolayısıyla söz konusu sözlüklerdeki bir kelimenin birinci anlamı, kelime bağlamsız söylendiğinde toplumca anlaşılan ilk anlamıdır. Toplumca benimsenmeyen bir anlamı, bir sözün birinci anlamı; toplumca benimsenmiş olanı, ikinci anlamı olarak sunmak toplumsal iletişime vasıta olması gereken çalışmalar için sorunlu bir durumdur (Karademir, 2016: 290).

Meseleyi bazı sorularla açalım:

-Ahlak göstergesi söylendiğinde genel Türkçe konuşur kitlesinin aklına ilk gelen anlam, "kişilerin uymak zorunda oldukları kurallar" mıdır?

Bizce hayır. Çünkü ortalama bir Türkçe konuşuru için ahlak'ın akla ilk gelen anlamı, toplumsal kurallar değil, kişinin manevi özellikleri ve bu özelliklerin kişinin davranışına yansımalarıdır: Zira iyi ahlaklı, güzel ahlaklı, temiz ahlaklı, kötü ahlaklı derken bu manaları kastediyoruz. Ayrıca ahlaklı $\neq$ ahlaksız karşıtlığında görüldüğü üzere ahlak'ın Türkçede tek başına da olumlu nitelikleri içkin bir gösterge olarak kullanılabildiği unutulmamalıdır. Bu anlamı ile ahlaklı demek hoş, iyi güzel vs. huyları/davranışları olan demektir. Dolayısıyla Güncel Türkçe Sözlük'ün ahlak için verdiği iki anlam yer değiştirmelidir. Yani 1. anlam, huylar; 2. anlam, kurallar olmalıdır.

Yaptığımız anketten elde edilen veriler de bu görüşümüzü destekler niteliktedir. Zira "toplumda insanların uyması gereken kurallar; din kurallarının bütünü” şeklinde ahlak'1, kural olarak açılayan bir iki örneğin dışında, 100'ü liseli, 100'ü üniversiteli olan 200 katılımcının \%100'üne yakını, ahlak'1 "bir kişinin olumlu ve olumsuz davranışları; bir kişinin davranış biçimi; terbiye; huy; insanın güzel davranış ve sözleri; üslup; edep; kalbin edebi” gibi davranış/huy eksenli ifadelerle açıklamışlardır.

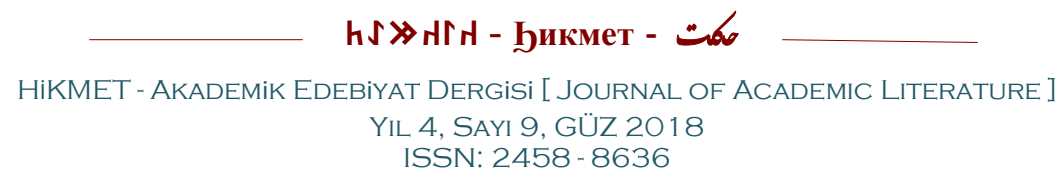


Şimdi de etik'in anlam sıralamasına bakalım:

-Türkçe konuşurlarına göre, etik'in akla ilk gelen anlamı Güncel Türkçe Sözlük'ün belirttiği gibi “töre bilimi” midir?

Bizim cevabımız yine hayırdır. Zira bizce etik, bir Türkçe konuşuru için, öncelikle, ahlak ve(ya) ahlaken uygun olan, toplumca hoş karşılanan'dır. Anılan anketimizin verileri de bu yöndedir. Zira 200 katılımcıdan sadece biri etik kavramını bilim olarak değerlendirmiştir. Geri kalanların büyük ekseriyeti "ahlak; ahlaka uygun (davranış); toplumun değer yargılarına uygun (davranış)" gibi birbirine yakın ifadelerle açıklamışlardır.

Katılımcıların verdiği cevapların kabaca tasnifi, genel bir durum tespiti için aşağıda sunulmuştur ${ }^{25}$ :

Tablo 5: Lise öğrencilerinin etik kavramı için verdikleri karşılıklar

\begin{tabular}{|c|c|c|}
\hline & Verilen karşılıklardan örnekler & \\
\hline $\begin{array}{l}\text { Uygun davraniş, hal } \\
\text { hareket mealinde olumlu } \\
\text { anlam yükleyenler }\end{array}$ & $\begin{array}{l}\text { uygun olan şey; olumlu veya uygun davranış; } \\
\text { hoş, iyi, nazik; kibar, cool olma; uyumlu olan; } \\
\text { uygun olan; görgülü, elit; nazikçe davranış; } \\
\text { güzel davranış; doğru; toplum için uygun } \\
\text { davranışlar; ahlak, doğru davranı̧; görgülü, } \\
\text { saygıll; sosyetik; her şeyi bilen, modern... }\end{array}$ & 39 \\
\hline $\begin{array}{l}\text { Atik'le (Çabuk davranan, } \\
\text { çevik) karıştıranlar }\end{array}$ & $\begin{array}{l}\text { etkin, aktif olan; girişken, çekinmeyen, ayak } \\
\text { uyduran; hızlı; bir işi başkasına göre daha } \\
\text { kolay yapan; aceleci; becerikli; pratik; } \\
\text { hareketli; enerjik; yerinde durmayan; çabuk; } \\
\text { düzenli, planlı... }\end{array}$ & 19 \\
\hline $\begin{array}{l}\text { "Etik değil." ifadesinden } \\
\text { hareketle olumsuz anlam } \\
\text { yükleyenler }\end{array}$ & $\begin{array}{l}\text { doğru olamayan durumlar, davranışlar; uygun } \\
\text { olmayan; olumsuz hareket; uygunsuz davranış; } \\
\text { halk tarafindan yanlış bakılan hal ve hareket; } \\
\text { güzel olmayan, çirkin... }\end{array}$ & 8 \\
\hline $\begin{array}{l}\text { Birbirinden farklı, ilgisiz } \\
\text { anlamlar yükleyenler }\end{array}$ & $\begin{array}{l}\text { antik; antika; eski; epik'in eş anlamlısı; açık, } \\
\text { anlaşılır; ona özgü; bitmiş, tükenmiş; konuşma } \\
\text { tarzı... }\end{array}$ & 15 \\
\hline $\begin{array}{l}\text { Herhangi bir karşıllk } \\
\text { veremeyenler }\end{array}$ & - & 19 \\
\hline \multicolumn{2}{|l|}{ Toplam } & 100 \\
\hline
\end{tabular}

${ }^{25}$ Liseli katılımcılar ile üniversiteli katılımcıların cevapları arasında anlamlı bir fark bulunduğundan veriler ayrı ayrı değerlendirilmiştir: 
Tablo 6: Üniversite öğrencilerinin etik kavramı için verdikleri karşılıklar

\begin{tabular}{|c|c|c|}
\hline \multicolumn{3}{|c|}{ Üniversite öğrencilerinin verdiği karş1lıklar } \\
\hline $\begin{array}{l}\text { Doğrudan "ahlak" } \\
\text { karş1lığını verenler ve/veya } \\
\text { "ahlak" ile ilişkilendirenler }\end{array}$ & $\begin{array}{l}\text { Ahlak; ahlaki; ahlaka uygun davranış; ahlaki } \\
\text { değerler; toplumda kendiliğinden oluşan ahlak } \\
\text { kuralları; yazılı olmayan evrensel ahlak } \\
\text { kuralları... }\end{array}$ & 54 \\
\hline \begin{tabular}{lrr} 
Toplumca & \multicolumn{2}{c}{ benimsenen } \\
davranış biçimi & ve/veya \\
davranış kuralı & olarak \\
açıklayanlar &
\end{tabular} & $\begin{array}{l}\text { Toplumun değer yargılarına uygun; uygun } \\
\text { davranış; doğru olan davranış; toplumca } \\
\text { doğruluğu kabul edilmiş; toplumda uyulması } \\
\text { gereken görgü kuralları; bazıları belirlenmiş, } \\
\text { bazıları kişinin vicdanına kalmış kurallar } \\
\text { bütünü... }\end{array}$ & 41 \\
\hline $\begin{array}{l}\text { "Ahlak bilimi” karşılı̆̆ } \\
\text { verenler }\end{array}$ & Ahlak kavramıyla ilişkili olup ahlak bilimidir. & 1 \\
\hline "Vicdan" karş1lığ1 verenler & Vicdan & 1 \\
\hline $\begin{array}{l}\text { Olumsuz } \\
\text { yükleyenler }\end{array}$ & Kaba & 1 \\
\hline "Mant1k” karş1lı̆g 1 verenler & Mantık & 1 \\
\hline $\begin{array}{l}\text { Herhangi bir karş1lık } \\
\text { vermeyenler }\end{array}$ & - & 1 \\
\hline Toplam & & 100 \\
\hline
\end{tabular}

Ahlak göstergesini adlandırmada liseli katılımcılarla üniversiteli katılımcılar arasında dikkate değer bir fark gözlenmediği, her iki grubun ahlak kavramını benzer ifadelerle anlamlandırdığı daha önce belirtilmişti. Tablolara göz atıldığında, ahlak'taki durumun tersine, etik'i adlandırmada iki grup arasında ciddi bir farkın bulunduğu anlaşılmaktadır. Zira tablolarda görüldüğü üzere liseli katılımcılar etik kavramını doğru anlamlandırmada zorlanmış, önemli bir kısmı ya etik'e ilgisiz anlamlar yüklemiş yahut herhangi bir anlam verememiştir. Buna karşın üniversiteli katılımcıların tamamına yakını etik kavramını doğru veya doğruya yakın kavramlarla açıklamışlardır. Bu durum, kanaatimizce, etik'in henüz ahlak kadar, topluma mal olmadığını, hala akademik/terimsel yönünün ağır bastığını göstermektedir.

Peki, akademik çevrelerde durum nasıldır?

İki kavramın ayrımına/ilişkisine dair açıklamalardan şu örneklere bakalım:

1. "Ahlak, kısaca insanların hayatın yönlendiren ilkeler topluluğu ve kurallar bütünü olarak tanımlanır. Ĕger bu ilkeler ve kurallar din, örf, adet gibi toplumsal yapıdan kaynaklaniyorsa genellikle 'moral' adı verilir. Şayet insan aklının bilgi ve tecrübesinin ürünü ise o zaman da etik denir. Kısacası dini temelli ahlak 'moral' felsefi temelli ahlak ise 'etik' adını alır. Günümüzde artık pek çok 
etikten söz edilmektedir: Global etik, biyoetik, medikal etik, biyomedikal etik, mikroetik gibi yeni kavramlar, hızla sözlüklerimize giriyor.” (Oktay, 2015: 15).

2. "Etik ile ahlâk terimleri, toplumda sıklıkla birbiri yerine kullanılabilen terimler olmasına rağmen, literatürde bu iki terimin farkl olduklarını tespit etmiş bulunmaktayız. Etiğin davranışlarda 'doğru ve yanlış' kavramını inceleyen bir felsefe olduğunu; ahlâkın ise daha çok davranışlarda uygulamaya yönelik bir kavram olduğunu ifade edebiliriz. Etik konusunda 19'uncu yüzylla kadar dini inançların ağırlıklı etkisi görüldüğ̈̈ ifade edilirken, sanayi devriminin ve Rus devriminin etkisiyle bu etkinin giderek zayıfladiğ bildirilmişstir." (Aktaş, 2014: 31).

3. "Ahlâk sözcüğü etik kavramından türetilmiştir. Etik daha çok ahlâk ilkelerine ilişkin felsefi çalışma olarak tanımlanabilmektedir." (Mahmutoğlu, t.y.: 231).

4. Ahlak; bir kişinin, bir grubun, bir halkın, bir toplumsal sınıfın, bir ulusun, bir kültür çevresinin vb. belli bir tarihsel dönemde yaşamına giren ve eylemlerini yönlendiren inanç, değer, norm, buyruk, yasak ve tasarımlar topluluğu ve ağı olarak karşımıza çıkar. (...) .

Ahlak, fiilen ve tarihsel olarak bireysel, grupsal, toplumsal düzeyde yaşanan bir fenomen olmasına karşıllk; etik, bu fenomeni ele alan, ahlak görüşlerini, öğretilerini irdeleyip sınıflandıran, aralarındaki benzerlik ve farklı1ıkları ortaya koyan, bunları karşılaştırıp eleştiren felsefe disiplinidir. ... Ahlaklar çokluğuna karşı etik tektir. Etik, Grekçe "ethos"; moral, Latince "mos" sözcüğünden gelir. "Ethos" da "mos" da, töre, gelenek, görenek, alışkanlık, yerleşik hale gelmiş duygululuk hali, karakter, huy, mizaç vb. anlamlara gelir. "Moral" karşılığı olarak kullandığımız ahlak sözcüğünün köken, ise, Arapça "hulk"a dayanır. Bu kök de yine töre, gelenek, alışkanlık, huy, karakter vb. anlamlara gelmektedir. Buna göre etik, moral ve ahlak, nüanslar göz ardı edilirse, aynı anlama sahip sözcükler olup etimolojilerine göre değil, felsefedeki anlamlarına göre birbirinden ayrilır.

Etik'in görevi, herhangi bir ahlak geliştirmek, ahlaklar çokluğuna bir yenisini eklemek ve insanlara bu ahlaka uyulmasını ögütlemek değildir. Etik, "ahlak" denen fenomeni inceleme alanıdır. Başka bir deyişle, etik, pratik bir etkinlik alanı olan ahlakı teorik bir inceleme konusu kılan felsefe disiplinidir.

Etik ve ahlak (moral) arasında yaptığımız ayrıma rağmen, günlük dilde, hatta felsefede, her iki sözcüğün birbiri yerine kullanılageldiğini de sik s1k görmekteyiz. Zira etikçilerin ahlak fenomenine ve çeşitli ahlak görüşlerine bakış ve değerlendiriş tarzlarına, kendileri farkında olsun veya olmasın şu veya bu ölçülerde belli bir ahlakın, tikel bir ahlak görüşünün bakış ve değerlendiriş tarzı sızmış, sinmiş olabilir.

Böyle durumlarda etik ile ahlak arasındaki sınırların belirsizleştiği, bunların çok defa iç içe girdikleri görülür. Dolayısıyla etik-ahlak ayrımı, her zaman belli ölçülerde bulanık bir ayrım olarak kalır². (Özlem, 2004: 17-24).

${ }^{26} \mathrm{Bu}$ alıntı özetlenmiştir. 
Şimdi bu açıklamaları özetleyerek değerlendirelim:

\section{Açıklama}

-Ahlak, dini temelli ve felsefi temelli ahlak olmak üzere ikiye ayrilır.

-Dini temelli ahlak'a moral denir.

-Felsefi temelli ahlak'a etik denir.

-Dolayısıyla ahlak, etik'i kapsar. Başka bir ifade ile etik, ahlak'ın kollarından biridir.

\section{Açıklama}

-Toplumda etik ile ahlak sıklıkla birbirinin yerine kullanılabilmektedir.

-Literatürde bu terimler şu iki farklı anlamda kullanılmaktadır:

-Etik, davranışlarda "doğru ve yanlış" kavramını inceleyen bir felsefedir.

- Ahlâk, daha çok davranışlarda uygulamaya yönelik bir kavramdır.

- Etik konusunda 19. yüzyıla kadar dini etkiler baskınken, sanayi ve Rus devrimlerinden sonra bu etki azalmıştır

\section{Açıklama}

-Ahlak sözcüğü etik kavramından türetilmiştir.

-Etik daha çok ahlâk ilkelerine ilişkin felsefî çalışmadır.

\section{Açıklama} etmektedir.

-Etik, moral ve ahlak etimolojik olarak hemen hemen aynı manaları ifade

- Moral ile ahlak felsefi terim olarak, anlamdaş olup etik'ten ayrılırlar.

- Ahlak (moral), terim anlamıyla bireysel ve toplumsal değer yargılarıdır; etik, bu değer yargılarını inceleyen bilimdir. Başka bir ifade ile ahlak/moral, pratik bir etkinlik alanı; etik, onları teorik bir inceleme konusu kılan felsefi disiplindir.

-Bu terimler arasında pratikte kavramsal olarak tam bir sinır çizilememekte, gerek günlük dilde gerekse felsefi çevrelerde söz konusu terimler birbirinin yerine kullanılmaktadır. Ahlak konusunu nesnel bir gözle inceleme konumunda bulunan etikçilerin görüşlerinde de belli bir ahlak görüşünün etkisi görülebilmektedir.

$\mathrm{Bu}$ verlerden şu sonuçalara ulaşmak mümkündür:

Genel Türkçe sözlüklerde olduğu gibi, akademik çevrelerde de etik ve ahlak kavramlarının anlam sınırlarına ilişkin bir belirsizlik söz konusudur. $\mathrm{Bu}$ durumun sebeplerini şöyle sıralamak mümkündür:

\section{a. Gereksiz alıntılama/kopyalama:}

Moral ve etik'in Türkçeye transfer edilmesi mübrem bir gereksinimden kaynaklanmış görünmemektedir. Zira Türkçede moral ve etik'ten maksat hemen her tür ince manayı ahlak eksenli terimlerle karşılamak mümkündür: Ferdi (bireysel, kişisel, şahsi) ahlak, içtimai (sosyal) ahlak, grup ahlakı, dini ahlak,

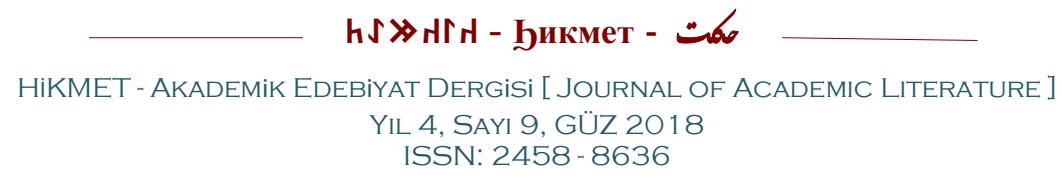


seküler ahlak, evrensel ahlak, Batı ahlakı, Doğu ahlakı, iş/meslek ahlakı, güzel ahlak, ahlaki değerler, ahlaki durumlar..

Şayet Özlem'in işaret ettiği gibi, etik'i alıntılamaktan maksat, ahlak olgusunu nesnel bir bakışla inceleyen bilimi karşılamaksa, onun için de Türkçede ahlakiyat veya ahlak bilimi mevcuttu. Ciddi bir ihtiyaçtan kaynaklanmadığı içindir ki, ahlak, moral ve etik'i, anlam sınırlarını çizerek nüanslı kullanma çabası gerektiği gibi sonuç vermemekte, bu konuda bir kavram karmaşası sürüp girmektedir. Ahlak göstergesi ve dil bilgisel bağlamları dilde var olduğu sürece bu çabanın tam manası ile netice verebileceğini düşünmek de güç görünmektedir.

Hal böyleyken, özellikle kimi akademik çevrelerde ahlak'a karşllık moral'i, ahlakiyat'a/ahlak bilimi'ne karşılık etik'i ikame etme çabasının altında üzerinde ayrıca durulması gereken kimi sosyo-psikolojik ve siyasal saikler yatıyor olmalıdır. Bu saikler, ayrı bir çalışma olarak edim bilim (pragmatics) ve söylem çözümlemesi (discourse analysis) gibi disiplinler açısından incelenmelidir.

b. Günlük kullanım anlamlarını göz ardı etme:

Günlük dildeki yaygın ve yerleşik bir göstergeyi, günlük kullanım manasından farklı bir manayla terimleştirme gayretleri çok defa suni ve sonuçsuz kalmaktadır. Ahlak, moral ve etik konusunda yaşanan kavram karmaşasının bir sebebi de bu olsa gerektir. Çünkü moral ve etik göstergelerine yüklenmek istenen terimsel mana ile günlük kullanım manaları örtüşmemektedir.

Moral göstergesi, genel Türkçe konuşur kitlesi açısından "ruh hali" anlamındadır ve köylüden kentliye hemen herkesin bu anlamı ile kullandığı bir göstergedir: Bu gün moralim iyi/bozuk, moral bozukluğu gibi. Yaptı̆̆ımız anketin sonucu da bu yöndedir. Zira 200 katılımcıdan sadece biri, moral için ahlak karşılığ vermiş, diğer bütün katılımcılar, duygu hali, duygu durumu, bir şeyleri yapmak için güç, o anki ruh halimiz, tahammül gücümüz, hayata tutunma gücü, insanın psikolojik durumu, motivasyon, güzel enerji, keyif... şeklinde, farklı ifadelerle de olsa, moral'i ruh hali ile ilişkilendirerek açıklamışlardır.

Türk Dil Kurumunun Güncel Türkçe Sözlük'ünün moral için verdiği anlam da benzer şekildedir: "moral -li isim Fransızca morale Bir insanın ruhsal gücü, manevi güç, maneviyat 'Morali bozuk bir insan.' " (http://www.tdk.gov.tr).

Moral'in bu yaygın ve yerleşik anlamını göz ardı ederek onu çok köklü olan ahlak terimi anlamında ve(ya) onun yerine kullanma gayreti, doğal olarak sonuçsuz kalmakta, gereksiz bir terim karmaşasına yol açılmaktadır.

Yine daha önce ifade edildiği gibi, etik göstergesi de ahlaki olan ve ahlak manaları ile günlük dile yerleşmiş durumdadır: Etik (ahlaki) değerler, etik (ahlaki) bir davranış, meslek etiği (meselek ahlakı) gibi. Bu yaygın ve yerleşik anlamına rağmen, onu ahlak'ı nesenel olarak inceleyen bilim olarak (ahlak bilimi) sınırlamak da yine neticesi kavram karmaşası olan boş bir çaba olarak kendini göstermektedir.

Bütün bunlara "Ahlak sözcügü etik kavramından türetilmiştir." ${ }^{27}$ gibi özensiz ifadeler ve burada sayamadığımız başka nüanslı kulllanımlar da eklenince konuyla ilgili kavram karmaşası içinden çıkılması zor şöyle bir oyuna dönüşmektedir:

${ }^{27}$ Arapça hulk'dan gelen ahlak'ın etik kavramından türediğini iddia etmek, şayet bir sürçülisan eseri değilse, önemli bir hatadır. 
-Ahlak moral'dir.

-Hayır, moral tam olarak ahlak değildir, ahlak’ın dinî olanıdır.

-Hayır, moral, ahlak değil, ruh halidir.

-Ahlak, etik'tir.

-Hayır, etik, ahlak'ın ladinî olanıdır.

-Hayır, ahlak'in evrensel olanıdır.

-Hayır, mesleki olanıdır.

-Hayır, bunları inceleyen bilimdir.

-Hayır, ahlak'a uygun olandır...

Hayır, hayır;

ahlak ahlak'tır, etik'tir, moral'dir; etik etik'tir, ahlak'tır, moral'dir

ve

moral, moral'dir, ahlak'tır, etik'tir...

\section{2.b. Ahlak ve etik göstergelerinin dil bilgisel bağlamları}

\section{b.1. Ahlak göstergesi}

Ahlak göstergesi; $+\hat{\mathbf{1}},+\mathrm{sal},+\mathrm{XX},+\mathrm{sXz}$ gibi ekleri alarak sıfat olarak kullanılabilir: ahlakî bir sorun, ahlaksal bakış açısı, ahlaklı bir insan, ahlaksız bir adam gibi. Ancak eksiz, her durumda isimdir. Dolayısıyla dil bilgisel bağlamları çoğunlukla isim tamlamalarıdır. Ahlak, isim tamlamalarında ya tamlayan ya da tamlanan görevindedir. Diğer yandan ahlak'ın, çeşitli eş dizimleri ile birlikte bağlama grupları kurduğu, sıfat tamlamalarında isim unsuru olarak görev yaptığı da gözlenir.

Ahlak göstergesinin söz konusu kullanımları ile ilgili olarak Türkçe Ulusal Derlemi'nden taradığımız bazı örnekler aşağıdaki gibidir:

\section{İsim tamlamaları}

ahlak alanı, ahlak anarşisi, ahlak anlayışı, ahlak anıtı, ahlak bağı, ahlak bekçileri, ahlak bildirgesi, ahlak bilgileri, ahlak bilgisi, ahlak bilinci, ahlak boşluğu, ahlak bozulmaları, ahlak daireleri, ahlak değerleri, ahlak dersi, ahlak dışı, ahlak doğruları, ahlak duyguları, ahlak dünyası, ahlak eğitimi, ahlak erozyonu, ahlak esasları, ahlak felsefesi, ahlak filozofu, ahlak fukarası, ahlak gelişimi, ahlak gevşekliği, ahlak görüşü, ahlak hareketi, ahlak hayatı, ahlak hukuku, adalet ve ahlak hususları, ahlak hükümleri, ahlak ilkeleri, ahlak kahramanları, ahlak kampanyası, ahlak kanununu ve yükümlülüğü, ahlak kodları, ahlak konuları, ahlak krizi, ahlak kuralı, ahlak kurumu, ahlak masası, ahlak mektebi, ahlak normları, ahlak notları, ahlak nutukları, ahlak okulları, ahlak ögeleri, ahlak ögretileri, ahlak öğretimi, ahlak ölçüleri, ahlak polisi, ahlak prensipleri, ahlak programı, ahlak risaleleri, ahlak sahası, ahlak sahibi, ahlak savaşçıları, ahlak savcısı, ahlak sınavı, ahlak sınırları, ahlak sorgulaması, ahlak sorunu, ahlak söylemi, ahlak suçu, ahlak tartışması, ahlak teorisi, ahlak toplulukları, ahlak unsuru, ahlak ve onur sayfası, ahlak yasası, ahlak zabıtalığı, (....) ahlak taahhütnamesi, ahlak teleolojisi, ahlak eksikliği, ahlak sağlığ 1 , ahlak düsturu, ahlak zafiyeti, ahlak numunesi, (yaygın) ahlak inanc1, ahlak vaizi, ahlak bozulması, ahlak beyannamesi, ahlak bozguncuları,

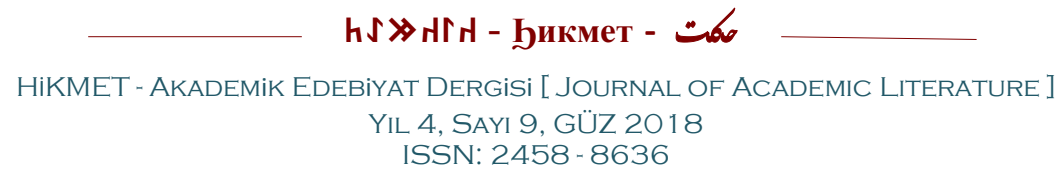


ahlak sembolü, ahlak komitesi, ahlak komisyonları, ahlak hukuku, ahlak sınıflandırması, ahlak kategorisi, ahlak vaazları, ahlak metafiziği, ahlak kültürü, ahlak ilmi, ahlak idesi, ahlak sevgisi, ahlak zemini, ahlak düşünürü, ahlak çerçevesi, ahlak düşkünü (ahlaksız), ahlak yoksunu, ahlak kaygıları,ahlak hocalığı, ahlak maskesi, ahlak tarzı, ahlak abidesi, ahlak savunucuları, ahlak hükmü, (genel) ahlak yararı, ahlak standardı, ahlak meselesi, ahlak bunalımı, ahlak seviyesi, ahlak tahlili, ahlak tezkiyesi, ahlak komiteleri, ahlak formülleri, ahlak bağlantıları, ahlak güzelliği, (izzet, onur, asalet gibi üstün) ahlak vasıfları, (siyasal) ahlak simgesi, (siyasi) ahlak misyonu...(Aksan, Y. vd., 2012).

\section{Sifat tamlamaları}

dini ahlak, cinsel ahlak, siyasal ahlak, benmerkezci ahlak, insan merkezci ahlak, ameli ve nazari ahlak... (Aksan, Y. vd., 2012).

\section{Bağlama grupları}

ahlak -din, ahlak ve dindarlık, ahlak ve dürüstlük, ahlak ve edep, ahlak ve erdem, ahlak ve fazilet, ahlak ve görenek, ahlak ve politika, ahlak ve terbiye, ahlaketik, ahlak-namus, ahlak ve siyaset (Aksan, Y. vd., 2012).

\section{b.2. Etik Göstergesi}

Etik göstergesi, eksiz haliyle hem sifat hem de isim olarak kullanılmaktadır. Peki, ahlak’taki ahlaklı $\neq$ ahlaksız karşıtlığında olduğu gibi etik’te de ekle sağlanan bir karşıtlık ilgisi var mıdır?

Google arama motorunda ve Türkçe Ulusal Derlemi'nde yaptığımız aramalarda az da olsa etik' in $+\mathrm{sXz}$ ile yapılmış örneklerine rastlanırken $+1 \mathrm{X}$ eki ile yapılmış örneklerine rastlanmamaktadır. + sXz'li üretimlerden bazı örnekler aşağıda sunulmuştur:

Etiksiz insanlar,

Ahlaksız etik yoktur ama etiksiz ahlak vardır,

Etiksiz efendinin tetikçi düzeni,

Zengin kocasına hesap sormayan etiksiz kadın,

Etiksiz bilim kördür, bilimsiz etik boştur,

Etiksiz medya,

Değersiz etik etiksiz değer olmaz,

Etiksiz ekonomi politikası kördür,

Etiksiz SGK'nin etiksiz motivasyon gezisi,

Etiksiz sanat- ahlaksız sanatçı (https://www.google.com.tr/).

Türkçe Ulusal Derlemi’nde Müjdat Gezen'in Galiba Ben Sanatçıyım adlı eserinden tespit edilen tek örneğin geçtiği metin, söz konusu üretimlerin benimsenip benimsenmediğini ortaya koyma açısından dikkat çekicidir:

“(...) rol buluyorum, o benim rolümü istiyor. Sonunda öyle oldu. Mehmet Ali benim rolümü oynad, ben oynamadım tabii. Filmden aldığı paraları kumarda kaybettiğini söylediler. Ahlaka neden etik diyorlar? Bu durumda ahlaksıza etiksiz mi diyeceğiz? Olmaz. Ahlaksıza ahlaksız demek daha uygundur.

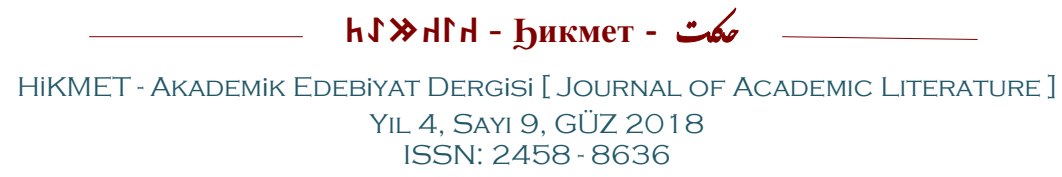


Ben bu işte Gani'ye mi, Mehmet'e mi, Ferdi'ye mi, Mehmet Ali'ye mi kızacă̆ıma karar veremediğim için hiçbirine klzmadım, oldu bitti. Onları ahlaklarıyla" (Aksan, Y. vd., 2012).

Etik göstergesinin kullanıldı̆̆ı bağlamlara gelince, Türkçe Ulusal Derlemi'nde yaptı̆̆ımız taramalara göre etik göstergesi daha çok sıfat ve isim tamlamalarında göze çarpmaktadır. Sifat tamlamalarında sıfat unsuru olarak işlev görürken isim tamlamalarında daha çok birinci unsur olarak kendini göstermektedir. Tespit edilen örnekler aşağıdaki gibidir:

\section{Sifat tamlamasında sifat unsuru olarak}

(kültürel ve) etik renkler, etik alan, etik algılamalar, etik amaç, etik anlam, etik bakış, etik bilgi, etik bilgisayar korsanlığı, etik boyut, etik çatı, etik çöküntü, etik davranış, etik değer, etik denetim, etik denge, etik ders, etik devlet, etik doğalcılar, etik donanım, etik dramlar, etik duruş, etik düzey, etik düzlem, etik eylem, etik gerekçe, etik gerekler, etik görüş, etik hatalar, etik hayal, etik hedefler, etik hususlar, etik içerik, etik ilişki, etik ilke, etik imkân, etik işletme, etik karar, etik kategoriler, etik kayg1, etik kodlar, etik konular, etik kriterler, etik kurallar, etik kuruluş, etik kurum kültürü, etik liderler, etik liderlik, etik mevzuat, etik muhbirlik, etik nitelikler, etik niyet, etik normlar, etik öncelikler, etik özne (insan), etik payda, etik prensipler, etik problemler, etik rejim, etik siyaset, etik sonuçlar, etik sorumluluk, etik sorunlar, etik standartlar, etik tartışmalar, etik tavır, etik temeller, etik tutarlılık, etik uygulamalar, etik uyum, etik üretim, etik yaklaşım, etik yapılanma, etik zaaf, etik zekâ...

\section{İsim tamlamasında isim unsuru olarak}

(adalet ve) etik anlaşmaları, (normatif) etik ahlakı, etik anlayışı, etik cehaleti, etik çalışmaları, etik çizgisi, etik dalı, etik derneği, etik dışı, etik içi (söylem), etik eğitimi, etik enstitüsü, etik görevlisi, etik hatt1, etik ihlali, etik iklimi, etik ilkesi, etik komisyonu, etik komitesi, etik kuram1, etik kurulu, etik normlar1, etik olanağ1, etik ödüller(i), etik öğreticileri, etik önermeleri, etik profesörü, etik programları, etik sahibi, etik sempozyumu, etik sorunsalları, etik sorunu, etik söylemleri, etik tarihi, etik teorileri, etik yaklaşımı, etik yoksunluğu, etik zirvesi (Aksan, Y. vd., 2012).

Şu örneklerde ise etik, fiilimsi grubunun isim unsuru olarak kullanılmıştır:

etik belirleyici, etik tanımayan... (Aksan, Y. vd., 2012).

Hiç şüphesiz etik ve ahlak göstergelerinin kullanıldığı bağlamlar yukarıda sıralananlarla sınırlı değildir. Sadece etik'in akademik literatürdeki terimsel kullanımları bile bir sözlükçe oluşturacak çokluktadır. Hançerlioğlu'nun (1976,) töre maddesi altında sıraladığı terimler bu durumu gösterir niteliktedir. Ancak çalışmanın çerçevesi gereği yukarıdaki örneklerle yetinilmiştir.

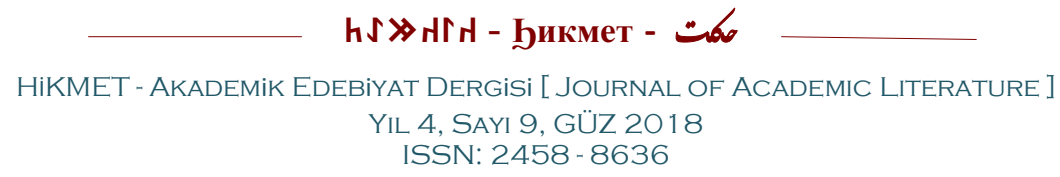




\section{Sonuç}

$\mathrm{Bu}$ çalışmada ahlak ve etik göstergelerinin Türkçenin söz varlığına katılma süreçleri ve günümüz Türkçesindeki kullanım keyfiyetleri ele alınmış ve şu sonuçlara ulaşılmıştır:

1. Ulaşılan verilere göre, ahlak göstergesinin Türkçenin söz varlığında tam olarak yerleștiği dönem Osmanlı Türkçesi dönemidir. Ahlak’tan önce Türkçede kullanılan başlıca göstergeler; k1lık, k1lk, kılınç ve hulk’tur. Osmanlı Türkçesinin başlarında kılık ve kılınç; sonlarında ise hulk kullanımdan düşmüş, bunların yerini büyük ölçüde ahlak göstergesi almıştır.

2. Etik göstergesinin Osmanlı'nın son dönemindeki Batılılaşma hareketleri ile birlikte Türkçeye girmiş olması muhtemel olsa da genel Türkçe sözlüklerde yer bulması 1980'den sonradır.

3. Kullanıldığı dil bilgisel bağlamlar, etik göstergesinin yazı dilinde geniş bir kullanım keyfiyetine ulaştığını, ancak henüz ahlak kadar herkesçe bilinen ve benimsenen bir gösterge halini almadığını göstermektedir. Bunun en açık delili, ahlaklı $\neq$ ahlaksız karşıt kullanımlarının yaygınlığına karşın etikli $\neq$ etiksiz karşıt kullanımlarının yok denecek kadar az oluşudur. Aynı şekilde, bazı çevrelerde ahlak'la müteradif olarak kullanılan moral de henüz ahlak anlamı ile yaygın bir kullanım düzeyine ulaşmamıştır.

4. Dil Devrimi'nden sonra ahlak ve etik göstergelerinin yerine ikame edilmek istenen töre, sağtöre, aktöre; törel göstergeleri Türkçe konuşurlarınca gereken ilgiyi görüp intişar etmemiştir.

5. Hemen her Türkçe kullanıcısı için önemli bir başvuru kaynağı niteliğinde olan Günel Türkçe Sözlük'ün ahlak ve etik göstergelerine getirdiği açıklamalar sözlük bilimsel açıdan hatalıdır. $\mathrm{Bu}$ maddelerin anlam tabakaları, toplumca benimsenen ilk anlamları esas alınarak düzenlenmelidir.

6. Akademik çevrelerde ahlak ve etik kavramlarının anlam sınırları ile ilgili ileri sürülen görüşler önemli farklılıklar göstermekte, bu durum, anılan kavramlarla ilgili bir terim karmaşasını netice vermektedir.

Söz konusu durumun temel sebepleri olarak gereksiz alıntılama/kopyalama ve terimlerin gündelik kullanım anlamlarını göz ardı etme sayılabilir. Bunlara şunları da eklemek mümkündür:

a. Ahlak ve etik kavramlarının çok sayıdaki disiplinle (din, eğitim, sosyoloji, psikoloji felsefe, iktisat...) ilgili oluşu ve dolayısıyla disiplin mensuplarının bu terimleri kendi literatürlerine göre kullanmaları,

b. Söz konusu terimlerin çok anlamlı oluşu ve özellikle etik'in hem sıfat hem de isim olarak kullanılma özelliği, kullanılmasi.

c. Terimlerin, gerekli dil hassasiyeti gösterilmeden gelişigüzel 


\section{Öneriler:}

1. Hulk (yaradılış) manasını içkin olan ahlak, sıradan bir Türkçe konuşuru için etik'e göre, din kavramı ile daha ünsiyetli, manevi çağrışım alanı daha güçlü bir göstergedir. Buna karşın, etik göstergesi ahlak'a nispetle daha seküler bir kavram olarak durmaktadır. Din ve ahlak ikilisindeki kavramsal tenasübün (unsurların kavramsal açıdan bir birinin mütemmimi/lazımı olma durumu), din ve etik ikilisinde olmayışı bunu açıkça göstermektedir. Dolayısıyla dil kullanıcılarının etik ve ahlak'tan birini tercihlerinde, Tanrı ve Allah göstergelerinden birini tercih etmelerindekine benzer bazı sosyo-psikolojik ve/veya siyasal saiklerin olup olmadığı edim bilim (pragmatics) ve söylem çözümlemesi (discourse analysis) gibi disiplinler açısından incelenebilir.

2. Tarihten bugüne ahlak kavramı ekseninde kullanılan göstergeler büyük bir yekûn teşkil etmektedir. Türkçede kullanılan ahlak kavramlarını bir araya getiren değerli çalışmalar mevcuttur (bk. Bilmen, 1967; Seyyar, 2015). Ancak araştırmamıza göre bu kavramları, tarihi olanları ve Türk lehçelerindeki karşılıkları ile kapsamlı bir şekilde bir araya getiren bir çalışma henüz yapılamamıştır. Deyim ve atasözleri başta olmak üzere konuyla ilgili dil bilgisel bağlamlar da göz önüne alınarak tarihten bugüne Türkçedeki ahlak ve etik kavramlarını Türk lehçelerindekilerle birlikte bir araya getiren tanıklı ansiklopedik bir ahlak terimleri/kavramları sözlüğü hazırlanabilir. Böyle bir sözlüğün hazırlanması, Türkçenin ahlaki söz varlığını ve Türk milletinin ahlak tasavvurunu tarihi seyri ile ortaya koyma açsından önemlidir.

\section{Kaynakça}

AKKUŞ, Metin (2018). Nefi Dîvânı.

http://ekitap.kulturturizm.gov.tr/Eklenti/57741,nefi-divanipdf.pdf?0

AKKUŞ, Muzaffer (1995). Kitab-ı Gunya. Ankara: TDK Yayınları.

AKSAN, D. (1976). Tartışmalı Sözcükler ve Özleştirme Sorunu. Ankara: TDK Yayınları.

AKSAN, Y. vd. (2012). Construction of the Turkish National Corpus (TNC). In Proceedings of the Eight International Conference on Language Resources and Evaluation (LREC 2012). İstanbul. Turkiye. http://www.lrecconf.org/proceedings/lrec2012/papers.html

AKTAŞ, K. (2014). Etik-Ahlâk İlişkisi ve Etiğin Gelişim Süreci. Uluslararası Yönetim ve Sosyal Araştırmalar Dergisi, 1(2), 22-32.

ARAT, R. R. (2006). Edib Ahmed B. Mahmud Yükneki, Atebetü'l-Hakâyık. Ankara: TDK Yayınları.

ARAT, R. R. (1979). Kutadgu Bilig III (İndeks), (Neşre hazırlayanlar: Kemal Eraslan, Osman Fikri Sertkaya, Nuri Yüce). İstanbul: Türk Kültürünü Araştırma Enstitüsü Yayınları, Edebiyat Fakültesi Basımevi.

ARAT, R. R. (1999). Kutadgu Bilig I (Metin). Ankara: TDK Yayınları.

ATA, A. (1998). Kısasü'l-Enbiyâ II (Dizin). Ankara: TDK Yayınları.

ATA, A. (1998). Nehcü'l-Ferâdîs III (Dizin-Sözlük). Ankara: TDK Yayınları.

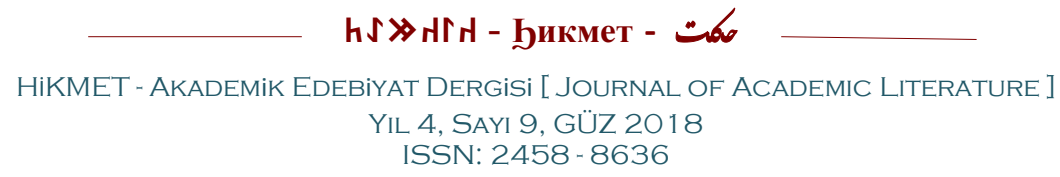


ATA, A. (2004), Türkçe İlk Kur'an Tercümesi-Karahanlı Türkçesi, Ankara: TDK Yayınları.

BAYAR, N. (2006). Açıklamalı Yeni Kelimeler Sözlüğü. Ankara: Akçağ Yayınları.

BAYAT, F. (2008). Orta Türkçe Sözlük. İstanbul: Yalın Yayıncılık.

BAYAT, F.- ALIYEVA, M. E. (2008). Eski Türkçe Sözlük. İstanbul: Yalın Yayınc1lı.

BİLMEN, Ö. N. (1967). Dini ve Felsefi Ahlak Lügatçesi. İstanbul: Bilmen Yayınları.

BÖLER, T. (2009). Kutadgu Bilig'de Ahlaklılık, Soyluluk ve Seçkinlik İfade Eden Sözler. Turkish Studies, 4(3), 397-418.

ÇAĞIRIRCI, M. (1989). Ahlâk. https://islamansiklopedisi.org.tr/ahlak\#1, Erişim Tarihi: 02.05.2018

ÇOLAK, G. (2015). Türkçede Fosil Kelimeler. Ankara: Grafiker Yayınları.

DEVELLİĞLU, F. (1988). Osmanlıca-Türkçe Lûgat. Ankara: Aydın Kitabevi.

ERCiLASUN, A. B. (2004). Baslangıçtan Yirminci Yüzyıla Türk Dili Tarihi. Ankara: Akçağ Yayınları.

ERCILASUN, A. B.- AKKOYUNLU, Z. (2014). Kâşsgarlı Mahmut, Dîvânu Lugâti't-Türk (Giriş-Metin-Çeviri-Notlar-Dizin). Ankara: TDK Yayınları.

ERDEM, M. (2014). Soğdca, Türkçedeki Soğdca Kelimeler ve Bunların Türkçeye Uyumları. Ankara Üniversitesi Dil ve Tarih-Coğrafya Fakültesi Türkoloji Dergisi, 21(1), 65-90.

ERGIN, M. (1997). Dede Korkut Kitabı II, Indeks- Gramer. Ankara: TDK Yayinlar1.

GÖZÜTOK, A. (2008). Türkiye Türkçesinde Karma Kelimeler. A.Ü. Türkiyat Araştırmaları Enstitüsü Dergisi, 36, 17-22.

GÜNER, G. (2006). Türkiye'de Kelime Etimolojisi Üzerine Yayımlanan Makalelere Dair Bir Bibliyografya Denemesi. Türklük Bilgisi Araştırmaları, 30/2: 77-93.

HANÇERLİĞLU, O. (1976). Felsefe Ansiklopedisi (Kavramlar ve Aklmlar), C. 1/A-D. İstanbul: Remzi Kitabevi.

KAHRAMAN, A. (1989). Ahlâk-1 Alâî. https://islamansiklopedisi.org.tr/ahlak-ialai, Erişim Tarihi: 02.05.2018.

KANAR, M. (2011). Eski Anadolu Türkçesi Sözlüğü. İstanbul: Say Yayınları.

KAPLAN, M. (1990). Hayriyye-i Nabi. Ankara: Ankara Üniversitesi Sosyal Bilimler Enstitüsü Doktora Tezi.

KARA, M. (2011). Ayrı Düşmüş Kelimeler. İstanbul: Kesit Yayınları.

KARADEMIR, F. (2016). Türkçe Sözlüklerde Meyve Adlarının Anlamlandırılışı. Dicle Üniversitesi Sosyal Bilimler Enstitüsü Dergisi, 16, 289-305.

KARTAL, A. (2009). Lügat-i Nâcî. Anara: TDK Yayınları.

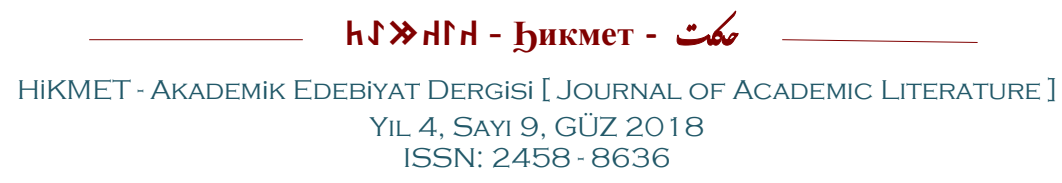


KURTOĞLU, O. (2017). Lebîb Dîvânı.

http://ekitap.kulturturizm.gov.tr/Eklenti/55756,lebib-divanipdf.pdf?0

KÜÇÜK, S. (t.y.). Bâkî Dîvânı.

http://ekitap.kulturturizm.gov.tr/Eklenti/10596,bakidivanisabahattinkucukpdf.pdf?0

LEVEND, A. S. (1963). Ümmet Çağında Ahlâk Kitaplarımız. Türk Dili Araştırmaları Yılliğı Belleten 1964, s. 89-115.

MAHMUTOĞLU, A. (t.y.). Etik ve Ahlâk; Benzerlikler, Farklılıklar ve İlişkiler. Türk İdare Dergisi, 224-249.

OCAK, A. Y. (1996). Fütüvvetnâme.

https://islamansiklopedisi.org.tr/futuvvetname, (ET: 02.05.2018)

OKTAY, A. S. (2015). Kinalızâde Ali Efendi ve Ahlâk- Alâî. İstanbul: İz Yayinc1lik.

ÖZLEM, D. (2004). Etik-Ahlak Felsefesi. İstanbul: İnkılâp Kitbevi.

ÖZMEN, M. (2001). Ahmed-i Dâ' '̂ Divanı I-II. Ankara: TDK Yayınları.

ÖZYetgiN, M. (2006). Tarihten Bugüne Türk Dili Alanı. (Conference) Chinese Academy of Social Science, Sino-Foreign Relationship Department of Institute of History, Beijing (CHINA) (23 January 2006). www.eurasianhistory.com.

ÖZYILDIRIM, A. E. (t.y.). Keçecizâde İzzet Molla- Mihnetkeşan. http://ekitap.kulturturizm.gov.tr/Eklenti/10693,kmgirispdf.pdf?0

PARLATIR, İ. vd. (2006). Lügat-i Cûdî (Müellifi: İbrahim Cudi Efendi). Ankara: TDK Yayınları.

PÜSKÜLlÜOĞLU, A. (1994). Öz Türkçe Sözlük (Genişletilmiş 11. Baskı). Ankara: Arkadaş Yayınevi.

SEYYAR, A. (2015). Ahlâk Terimleri (Ansiklopedik Sözlük). İstanbul: Rağbet Yayınlar1.

Şemsettin Sami (t.y.). Kâmus-ı Türkî. İstanbul: Çağrı Yayınları.

ŞEN, M. (2012). Tanrı Kelimesi Üzerine. VII. Uluslararası Türk Dili Kurultayında (24 - 28 Eylül 2012) Sunulan Bildiri, Ankara.

ŞENYAPILI, Ö. (2003). Her Sözcügüün Bir Hikâyesi Vardır. Ankara: ODTÜ Geliştirme Vakfı Yayınları.

TATÇI, M. (t.y.). Yunus Emre Divant.

http://ekitap.kulturturizm.gov.tr/Eklenti/10662,girispdf.pdf?0

TEKIN, T. (2003). Orhon Yazıtları. Ankara: Sanat Kitabevi.

TIETZE, A. (2002). Tarihi ve Etimolojik Türkiye Türkçesi Lugatı. İstanbul: Simurg Yayınc1l1k.

TOPARLI, R. vd. (2003). Kıpçak Türkçesi Sözlüğü. Ankara: TDK Yayınları.

TULUM, M. (2011). 17. Yüzyll Türkçesi Söz Varlığl (Meninski'nin Thesaurus'u ve XVI Yüzyll İstanbul Türkçesi. Ankara: TDK Yayınları.

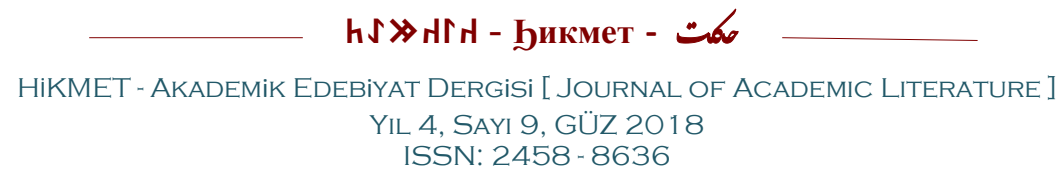


Türk Dil Kurumu (1944). Türkçe Sözlük. İstanbul: Cumhuriyet Basımevi.

Türk Dil Kurumu (1959). Türkçe Sözlük. Ankara: Yeni Matbaa.

Türk Dil Kurumu (1974). Türkçe Sözlük. Ankara: Bilgi Basımevi.

Türk Dil Kurumu (1978). Özleştirme Kılavuzu. Ankara: TDK Yayınları.

Türk Dil Kurumu (1983). Türkçe Sözlük. Ankara: TDK Yayınları.

Türk Dil Kurumu (1996). XIII. Yüzyıldan Beri Türkiye Türkçesiyle Yazılmış Kitaplardan Toplanan Tanıklarlyla Tarama Sözlüğü, IV. C. Ankara: TDK Yayınları.

Türk Dil Kurumu (1998). Türkçe Sözlük. Ankara: TDK Yayınları.

ULUDAĞ, S. (1996). Fütüvvet. https://islamansiklopedisi.org.tr/futuvvet, Erişim Tarihi: 02.05 .2018

ÜNLÜ, M. (1977). Öz Türkçe Sözlük. İstanbul: İnkılap ve Aka Kitabevleri.

ÜNLÜ, S. (2012a). Karahanlı Türkçesi Sözlüğ̈̈. Konya: Eğitim Yayınları.

ÜNLÜ, S. (2012b). Harezm-Altınordu Türkçesi Sözlüğü. Konya: Eğitim Yayınları.

ÜNLÜ, S. (2013). Çağatay Türkçesi Sözlüğ̈̈. Konya: Eğitim Yayınları.

ÜŞENMEZ, E. (2010). Karahanlı Türkçesi Sözlüğü. İstanbul: Doğu Kitabevi.

YAVUZ, K. (2000). Garib-Nâme (Müellifi: Âşık Paşa). http://ekitap.kulturturizm.gov.tr/TR,78417/asik-pasa---garib-name.html

http://lugatim.com/s/variyet

http://www.tdk.gov.tr 